\title{
Holocene and Eemian sea surface temperature trends as revealed by alkenone and $\mathrm{Mg} / \mathrm{Ca}$ paleothermometry
}

\author{
G. Leduc ${ }^{\mathrm{a}, *}$, R. Schneider ${ }^{\mathrm{a}}$, J.-H. Kim ${ }^{\mathrm{b}}$, G. Lohmann ${ }^{\mathrm{c}}$ \\ ${ }^{a}$ Institute of Earth Sciences, Geology Department; Kiel University; Ludewig-Meyn-Str. 10, D-24118 Kiel, Germany

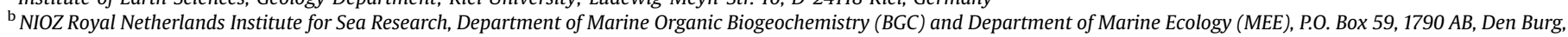 \\ Texel, The Netherlands \\ ${ }^{\mathrm{c}}$ Alfred Wegener Institute for Polar and Marine Research, Bussestr. 24, D-27570 Bremerhaven, Germany
}

\section{A R T I C L E I N F O}

\section{Article history:}

Received 29 July 2009

Received in revised form

24 December 2009

Accepted 6 January 2010

\begin{abstract}
A B S T R A C T
In this study we review a global set of alkenone- and foraminiferal $\mathrm{Mg} / \mathrm{Ca}$-derived sea surface temperatures (SST) records from the Holocene and compare them with a suite of published Eemian SST records based on the same approach. For the Holocene, the alkenone SST records belong to the actualized GHOST database (Kim, J.-H., Schneider R.R., (2004). GHOST global database for alkenone-derived Holocene seasurface temperature records. Available from: http://www.pangaea.de/Projects/GHOST.), while the Mg/ Ca-derived SST database represents a new compilation. The actualized GHOST database not only confirms the SST changes previously described but also documents the Holocene temperature evolution in new oceanic regions such as the Northwestern Atlantic, the eastern equatorial Pacific, and the Southern Ocean. A comparison of Holocene SST records stemming from the two commonly applied paleothermometry methods reveals contrasting - sometimes divergent - SST evolution, particularly at low latitudes where SST records are abundant enough to infer systematic discrepancies at a regional scale. Opposite SST trends at particular locations could be explained by out-of-phase trends in seasonal insolation during the Holocene. This hypothesis assumes that a strong contrast in the ecological responses of coccolithophores and planktonic foraminifera to winter and summer oceanographic conditions is the ultimate reason for seasonal differences in the origin of the temperature signal provided by these organisms. As a simple test for this hypothesis, Eemian SST records are considered because the Holocene and Eemian time periods experienced comparable changes in orbital configurations, but had a higher magnitude in insolation variance during the Eemian. For several regions, SST changes during both interglacials were of a similar sign, but with higher magnitudes during the Eemian as compared to the Holocene. This observation suggests that the ecological mechanism shaping SST trends during the Holocene was comparable during the penultimate interglacial period. Although this "ecology hypothesis" fails to explain all of the available results, we argue that any other mechanism would fail to satisfactorily explain the observed SST discrepancies among proxies.
\end{abstract}

(c) 2010 Elsevier Ltd. All rights reserved.

\section{Introduction}

Interglacial periods of the Late Pleistocene epoch such as the Holocene are marked by minor climate changes when they are compared to glacial periods (Dansgaard et al., 1993; Mayewski et al., 2004). Although less spectacular than glacial climate instabilities, significant long-term Sea Surface Temperature (SST) trends arising from paleotemperature reconstructions clearly mark the Holocene epoch (e.g. Marchal et al., 2002; Kim et al., 2004). A

\footnotetext{
* Corresponding author.

E-mail address: gl@gpi.uni-kiel.de (G. Leduc).
}

consistent regional SST evolution can be identified when comparing multiple SST records from various ocean basins (Kim and Schneider, 2004). Compilations like the global database for alkenone-derived Holocene SST records (GHOST, Kim and Schneider, 2004) highlight the usefulness of these efforts in detecting regional climate signals.

In the framework of a model-data comparison study performed to identify and explain apparent spatial and temporal Holocene SST patterns, the GHOST database allowed to point out geographic coherencies and discrepancies in long-term SST trends over the last 7000 years (Kim et al., 2004), in order to determine major modes of Holocene climatic variability (Rimbu et al., 2003, 2004) and to discuss the role of orbital forcing (Lorenz and Lohmann, 2004). The 
latter study suggests that Holocene surface ocean temperatures have experienced opposite trends between low and high latitudes, and that a shift in the season of maximum insolation during the Holocene at low latitudes may have accounted for changes in the seasonal timing of phytoplankton production of alkenones from which the SST signal was derived (Lorenz et al., 2006). These modelling studies, as well as ongoing discussions regarding SST proxy specific dependencies on seasonally varying surface water conditions - such as the thermocline depth or the temperature range of the mixed layer - still question the significance of singleproxy-based SST reconstructions at global or regional scales. More importantly, global databases are ultimately used as benchmarks for model evaluations, so that efforts to refine proxy significance assessments are of crucial importance.

The main purpose of this study was to supply a state-of-the-art knowledge for Holocene SST trends, as estimated from marine sediment cores, using two commonly used SST proxies, i.e. alkenone- and $\mathrm{Mg} / \mathrm{Ca}$-based paleothermometry, and to make a first attempt to compare Holocene and Eemian SST patterns on a global scale. The Holocene GHOST database had some oceanic regions under-represented, but alkenone SST records recently published and considered in this study now fill gaps for key locations and better confirm the regional SST evolution identified in the former version of the GHOST database. Additionally, a new synthesis of SST records based on $\mathrm{Mg} / \mathrm{Ca}$ ratios measured on planktonic foraminifera is presented for comparison with alkenone SST records. Although the spatial coverage of $\mathrm{Mg} / \mathrm{Ca}$ SST records is less than the updated alkenone-derived GHOST database, $\mathrm{Mg} / \mathrm{Ca}$ SST records often provide a very different picture of Holocene SST evolution than those formerly described by alkenone SST records. Our comparison suggests that the seasonal influence on the paleotemperature signal should be considered much more extensively when attempting to reconstruct regional SST patterns. A comparison between selected SST records covering both the Holocene and the Eemian suggests that our hypothesis is also valid for other interglacial periods. However, more extensive studies regarding Eemian SST trends are required in order to refute or confirm this ecological hypothesis.

\section{Theoretical background}

As pointed out by Huybers and Curry (2006), the seasonal cycle of SST is massive and may impact climate variability well beyond the annual cycle. Without considering dynamic effects such as atmospheric or oceanic feedbacks, a likely reason for the net impact of seasonality in climate variability on Milankovitch timescales involves a climate sensitivity weighted toward one particular season (Laepple and Lohmann, 2009).

The planktonic organisms that generate geologic signals of SST are also influenced by climate on a seasonal timescale. Indeed, most - if not all - studies focused on changes in the seasonal flux of planktonic organisms in the modern ocean report strong seasonal variations in the flux of foraminifera (see e.g. Thunell et al., 1983 for the Eastern Equatorial Pacific (EEP); Tedesco and Thunell, 2003 for the Western Equatorial Atlantic (WEA); Mohtadi et al., 2009 for the Indonesian archipelago; Schiebel and Hemleben, 2000 for the North Atlantic) and of alkenone-producing coccolithophorids (see e.g. the review by Iglesias-Rodriguez et al., 2002). Huybers and Wunsch (2003) have shown how long-term changes in orbital parameters without mean-annual insolation changes - such as precession - together with one seasonal-weighted proxy can generate low-frequency variability through interferences between climate recorders and seasonality (Huybers and Wunsch, 2003). For our case, if climate recorders such as coccolithophorids and/or planktonic foraminifera have overwhelmingly sampled one given season during interglacial periods, then the resulting geologic signal for SST in sediments has to be assigned to one season rather than to a mean-annual SST.

Our analysis was undertaken to address this issue by comparing SST records spanning the Holocene using two global databases derived from independent paleothermometers, in order to decipher whether these organisms had different seasonal preferences due to contrasting ecological behaviour. If it is the case for the global dataset, then SST records are interpreted in terms of seasonal rather than in terms of mean-annual SST records, as for any precessional signal found in a given climate record.

\section{Methodology}

The methodology used for the construction of the alkenonebased GHOST database is extensively described elsewhere (Kim et al., 2004). The same methodology has been adopted for the compilation of the $\mathrm{Mg} / \mathrm{Ca}$-derived SST database. These two SST proxies have the strong advantage over other SST proxies to be reproducible in the laboratory, so the relationship between temperature and the proxy - although empirical - is rigorously assessed and quantified under controlled environmental conditions.

In order to illustrate fields of Holocene SST changes on a map we adopted the strategy of calculating SST changes over the last $10 \mathrm{ka}$ by subtracting the estimated temperature from core-top SST values from the SST estimated for the $10 \mathrm{ka}$ interval (Table 1). Core-top estimations were computed by calculating the average of the available SST data spanning the last 1000 years (Table 1). Data spanning the 1000-2000 year interval were determined for sediment records where the core top was missing. The $10 \mathrm{ka}$ time slice averaged all of the available data spanning the 9.5-10.5 ka time interval (Table 1). The difference between the core top and the 10 ka time slice ultimately provides the calculated Holocene SST trend of a given SST record, assumed here to be linear to a firstorder (see discussion in Section 3).

This approach has the advantage of helping us to roughly visualize the sign of the main SST changes, i.e. a broad "warming" or "cooling" over the last $10 \mathrm{ka}$. However, in some particular areas such as, e.g., those surrounding the North Atlantic Ocean, a broad maximum in temperature may have occurred later than $10 \mathrm{kyr}$ BP because other climate feedbacks operate in this area (Renssen et al., 2009). The Mediterranean Sea, the Southern Ocean as well as some low-latitude records are indeed marked by mid-Holocene SST inflections, making the Holocene climate optimum occur between 10 and 6 kyr BP. In our analysis, most of the Holocene SST records that we utilized to compute global maps of SST trends are shown later in the discussion in order to visualize the shape of the SST records. In most cases, Holocene signs of SST change would be insensitive if the last $6 \mathrm{kyr}$ BP rather than the entire Holocene were considered since a climate optimum often occurs during the early Holocene.

In spite of a recognized potential bias in alkenone-based SST reconstructions linked to alkenone production in the thermocline, to the long-distance alkenone advection by oceanic currents and/or to a differential degradation of C37:3 and C37:2 alkenones within the sediment (see discussion in Conte et al., 2006 and references therein), alkenone-based thermometry is widely used as a SST proxy. Since the global core-top calibration equation of Müller et al. (1998) is remarkably well correlated with annual-mean SST, most of the alkenone-derived SST records are implicitly interpreted in terms of annual-mean SST. The alkenone-derived paleotemperature estimates are based on the conversion of the abundance ratios of long-chain unsaturated alkenones with two to three double bonds into SST using the calibration from the original referenced publications. The alkenone SST proxy accuracy and precision has been internationally calibrated and standardized amongst 24 laboratories worldwide (Rosell-Melé et al., 2001). The 
Table 1

Holocene (0-10 ka) and Eemian (126-115 ka) alkenone and $\mathrm{Mg} / \mathrm{Ca}$ SST dataset used to generate Figures 1, 2 and 4.

\begin{tabular}{|c|c|c|c|c|c|c|c|c|c|}
\hline \multicolumn{10}{|c|}{ Alkenone-based Holocene SST trends } \\
\hline Core name & $\begin{array}{l}\text { Latitude } \\
\left({ }^{\circ} \mathrm{N}\right)\end{array}$ & $\begin{array}{l}\text { Longitude } \\
\left({ }^{\circ} \mathrm{E}\right)\end{array}$ & $\begin{array}{l}\text { Water depth } \\
(\mathrm{m})\end{array}$ & $\begin{array}{l}\text { Mean Holocene } \\
\text { sedimentation } \\
\text { rate }\left(\mathrm{cm} \mathrm{ka}^{-1}\right)\end{array}$ & $\begin{array}{l}\text { coretop } \\
\text { SST }\left({ }^{\circ} \mathrm{C}\right)\end{array}$ & $\begin{array}{l}10 \mathrm{ka} \\
\operatorname{SST}\left({ }^{\circ} \mathrm{C}\right)\end{array}$ & $\begin{array}{l}\text { Holocene } \\
\text { SST trend } \\
\left({ }^{\circ} \mathrm{C}\right)\end{array}$ & Alkenone calibration & Reference \\
\hline MD952015 & 58.762 & -25.958 & 2630 & 60 & 11.4 & 12.3 & -0.9 & Müller et al. (1998) & Marchal et al. (2002) \\
\hline IOW 225517 & 57.667 & 7.091 & 293 & 40 & 11.5 & 13.4 & -1.9 & Müller et al. (1998) & Emeis et al. (2003a) \\
\hline GGC15 & 48.168 & 151.337 & 1980 & 6 & 10.9 & 8.8 & 2.1 & Müller et al. (1998) & Ternois et al. (2000) \\
\hline JT96-0909pс & 48.9117 & -126.89 & 920 & 6 & 10.1 & 11.5 & -1.4 & Müller et al. (1998) & Kienast and McKay (2001) \\
\hline ODP $1019 \mathrm{C}$ & 41.682 & -124.93 & 980 & 42 & 11.5 & 12.1 & -0.6 & Prahl et al. (1988) & Barron et al. (2003) \\
\hline M44-KL71 & 40.842 & 27.763 & 566 & 12 & 16.7 & 11.6 & 5.1 & Müller et al. (1998) & Sperling et al. (2003) \\
\hline SU81-18 & 37.767 & -10.1833 & 3135 & 15 & 17.7 & 18.3 & -0.6 & Prahl et al. (1988) & Bard et al. (2000) \\
\hline M40-4-SL78/78MUC8 & 37.036 & 13.19 & 470 & 26 & 17.2 & 18.6 & -1.4 & Müller et al. (1998) & Emeis and Dawson (2003) \\
\hline M39-008 & 36.382 & -7.077 & 576 & 33 & 20.0 & 20.9 & -0.9 & Müller et al. (1998) & Cacho et al. (2001) \\
\hline GeoB 5901-2 & 36.38 & -7.071 & 574 & 27 & 19.2 & 20.1 & -0.9 & Prahl et al. (1988) & Kim et al. (2004) \\
\hline MD95-2043 & 36.1433 & -2.62167 & 1841 & 36 & 18.4 & 19.0 & -0.6 & Müller et al. (1998) & Cacho et al. (1999) \\
\hline BS79-38 & 38.412 & 13.577 & 1489 & 22 & 16.9 & 18.2 & -1.3 & Müller et al. (1998) & Cacho et al. (2001) \\
\hline BS79-33 & 38.262 & 14.03 & 1282 & 16 & 16.5 & 19.5 & -3.0 & Müller et al. (1998) & Cacho et al. (2001) \\
\hline RL 11 & 36.746 & 17.7175 & 3376 & 4 & 19.2 & 17.8 & 1.4 & Müller et al. (1998) & Emeis et al. (2000) \\
\hline ODP 1017E & 34.535 & -121.107 & 955 & 22 & 15.3 & 13.6 & 1.7 & Prahl et al. (1988) & Ostertag-Henning and Stax (2000) \\
\hline ODP 967D & 34.0708 & 32.7255 & 2551 & 13 & 23.2 & 17.6 & 5.6 & Müller et al. (1998) & Emeis et al. (2000) \\
\hline ST.14 & 32.668 & 138.455 & 3252 & 9 & 22.3 & 22.2 & 0.1 & Prahl et al. (1988) & Sawada and Handa (1998) \\
\hline ST.19 & 31.095 & 138.665 & 3336 & 10 & 23.4 & 22.5 & 0.9 & Prahl et al. (1988) & Sawada and Handa (1998) \\
\hline GeoB 5844-2 & 27.7135 & 34.6817 & 963 & 7 & 26.8 & 25.6 & 1.2 & Prahl et al. (1988) & Arz et al. (2003) \\
\hline SO90-93KL & 23.583 & 64.217 & 1802 & 6 & 27.4 & 26.6 & 0.8 & Müller et al. (1998) & Schulz et al. (2002) \\
\hline LAPAZ21P & 22.99 & -109.467 & 624 & 6 & 25.0 & 24.9 & 0.1 & Prahl et al. (1988) & Herbert et al. (2001) \\
\hline ODP $658 C$ & 20.75 & -18.5833 & 2263 & 21 & 20.4 & 19.5 & 0.9 & Prahl et al. (1988) & Zhao et al. (1995) \\
\hline $17940-2$ & 20.1167 & 117.383 & 1727 & 55 & 26.8 & 25.1 & 1.7 & Müller et al. (1998) & Pelejero et al. (1999) \\
\hline SO93-126KL & 19.973 & 90.034 & 1253 & 8 & 27.8 & 27.2 & 0.6 & Sonzogni et al. (1997) & Kudrass et al. (2001) \\
\hline BOFS $31 \mathrm{~K}$ & 19.000 & -20.167 & 3300 & 21 & 20.8 & 21.1 & -0.3 & Prahl et al. (1988) & Zhao et al. (1995) \\
\hline SCS90-36 & 17.995 & 111.494 & 2050 & 4 & 26.4 & 24.9 & 1.5 & Prahl et al. (1988) & Huang et al. (1997) \\
\hline 74KL & 14.321 & 57.347 & 3212 & 9 & 27.3 & 26.6 & 0.7 & Prahl et al. (1988) & Kim et al. (2004) \\
\hline M35003-4 & 12.0833 & -61.25 & 1299 & 19 & 28.2 & 26.9 & 1.3 & Müller et al. (1998) & Rühlemann et al. (1999) \\
\hline TY93-905 & 11.0667 & 51.95 & 1567 & 26 & 25.7 & 25.3 & 0.4 & Prahl et al. (1988) & Kim et al. (2004) \\
\hline ODP $1002 \mathrm{C}$ & 10.7122 & -65.1697 & 893 & 43 & 24.8 & 24.8 & 0.0 & Prahl et al. (1988) & Herbert \& Schuffert (2000) \\
\hline MD77194 & 10.4667 & 75.2333 & 1222 & 17 & 27.5 & 27.4 & 0.1 & Prahl et al. (1988) & Sonzogni et al. (1998) \\
\hline ODP $1078 C$ & -11.92 & 13.4 & 426 & 42 & 24.9 & 23.7 & 1.2 & Müller et al. (1998) & Kim et al. (2003) \\
\hline GeoB 1023-5 & -17.158 & 11.008 & 1978 & 25 & 20.8 & 21.1 & -0.3 & Müller et al. (1998) & Kim et al. (2002a) \\
\hline MD79257 & -20.4 & 36.3333 & 1262 & 34 & 26.9 & 26.3 & 0.6 & Prahl et al. (1988) & Sonzogni et al. (1998) \\
\hline GIK 17748-2 & -32.75 & -72.0333 & 2545 & 12 & 16.3 & 16.6 & -0.3 & Prahl et al. (1988) & Kim et al. (2002b) \\
\hline M40-4SL87 & 38.988 & 4.023 & 1913 & 3 & 15.7 & 15.8 & -0.1 & Müller et al. (1998) & Emeis et al. (2003b) \\
\hline MD85674 & 3.183 & 50.433 & 4875 & 5 & 26.8 & 26.6 & 0.2 & Prahl et al. (1988) & Bard et al. (1997) \\
\hline CH07-98-GGC19 & 36.867 & -74.567 & 1049 & 27 & 14.6 & 18.1 & -3.5 & Prahl et al. (1988) & Sachs (2007) \\
\hline OCE326-GGC30 & 43.882 & -62.8 & 250 & 28 & 8.6 & 14.9 & -6.3 & Prahl et al. (1988) & Sachs (2007) \\
\hline OCE326-GGC26 & 43.483 & -54.867 & 3975 & 36 & 8.8 & 16.5 & -7.7 & Prahl et al. (1988) & Sachs (2007) \\
\hline KNR176-JPC32 & 4.847 & -77.963 & 2200 & 26 & 27.0 & 24.9 & 2.1 & Prahl et al. (1988) & Pahnke et al. (2007) \\
\hline MD02-2529 & 8.206 & -84.122 & 1619 & 33 & 28.9 & 27.3 & 1.6 & Sonzogni et al. (1997) & Leduc et al. (2007) \\
\hline ODP 1233 & -41.008 & -74.45 & 838 & 129 & 14.0 & 15.6 & -1.6 & Müller et al. (1998) & Kaiser et al. (2005) \\
\hline MD972120 & -45.534 & 174.931 & 1210 & 16 & 10.2 & 13.1 & -2.9 & Prahl et al. (1988) & Pahnke and Sachs (2006) \\
\hline GeoB 3910-2 & -4.0245 & -36.345 & 2362 & 5 & 27.1 & 26.7 & 0.4 & Prahl et al. (1988) & Jaeschke et al. (2007) \\
\hline GeoB 4905-4 & 2.5 & 9.39 & 1328 & 20 & 27.0 & 25.2 & 1.8 & Prahl et al. (1988) & Weldeab et al. (2007b) \\
\hline U938 & -45.51 & 179.5 & 2700 & 4 & 13.8 & 14 & -0.2 & Prahl et al. (1988) & Sikes et al. (2002) \\
\hline GeoB6518-1 & -5.588 & 11.222 & 962 & 36 & 25.0 & 24.7 & 0.3 & Müller et al. (1998) & Schefuß et al. (2005) \\
\hline MD03-2611 & -36.733 & 136.55 & 2420 & 27 & 17.9 & 18.9 & -1.0 & Müller et al. (1998) & Calvo et al. (2007) \\
\hline MD01-2412 & 44.527 & 145.042 & 1225 & 100 & 12.3 & 10.8 & 1.5 & Prahl et al. (1988) & Harada et al. (2006) \\
\hline
\end{tabular}

要

(continued on next page) 


\begin{tabular}{|c|c|c|c|c|c|c|c|c|c|c|c|c|}
\hline \multicolumn{13}{|c|}{ Alkenone-based Holocene SST trends } \\
\hline Core name & \multirow{2}{*}{$\begin{array}{l}\begin{array}{l}\text { Latitude } \\
\left({ }^{\circ} \mathrm{N}\right)\end{array} \\
-43.44 \\
\end{array}$} & $\begin{array}{l}\text { Longitude } \\
\left({ }^{\circ} \mathrm{E}\right)\end{array}$ & \multicolumn{2}{|c|}{$\begin{array}{l}\text { Water depth } \\
\text { (m) }\end{array}$} & \multirow{2}{*}{$\begin{array}{l}\begin{array}{l}\text { Mean Holocene } \\
\text { sedimentation } \\
\text { rate }\left(\mathrm{cm} \mathrm{ka}^{-1}\right)\end{array} \\
7\end{array}$} & \multicolumn{2}{|c|}{$\begin{array}{l}\text { coretop } \\
\text { SST }\left({ }^{\circ} \mathrm{C}\right)\end{array}$} & $\begin{array}{l}10 \mathrm{ka} \\
\text { SST }\left({ }^{\circ} \mathrm{C}\right)\end{array}$ & $\begin{array}{l}\text { Holocene } \\
\text { SST trend } \\
\left({ }^{\circ} \mathrm{C}\right)\end{array}$ & \multicolumn{2}{|c|}{ Alkenone calibration } & Reference \\
\hline & & 167.851 & \multicolumn{2}{|c|}{1556} & & \multicolumn{2}{|c|}{14.7} & 16.6 & -1.9 & \multicolumn{2}{|c|}{ Müller et al. (1998) } & Barrows et al. (2008) \\
\hline V19-27 & -0.467 & -82.667 & \multirow{2}{*}{\multicolumn{2}{|c|}{1373}} & 6 & \multicolumn{2}{|c|}{26.5} & 25.3 & 1.2 & \multicolumn{2}{|c|}{ Prahl et al. (1988) } & Koutavas and Sachs (2008) \\
\hline V19-28 & -2.51 & -84.65 & \multirow{2}{*}{\multicolumn{2}{|c|}{$\begin{array}{l}2720 \\
3091\end{array}$}} & 5 & 24.0 & & 23.5 & 0.5 & Prahl et al. (198 & & Koutavas and Sachs (2008) \\
\hline V19-30 & -3.383 & -83.517 & & & 7 & 22.6 & & 22.2 & 0.4 & Prahl et al. (198 & & Koutavas and Sachs (2008) \\
\hline GeoB 7926-2 & 20.217 & -18.45 & 250 & & 11 & 20.4 & & 19.7 & 0.7 & Prahl et al. (198 & & Romero et al. (2008 \\
\hline MD95-2042 & 37.799 & -10.166 & 314 & & 30 & 17.9 & & 17.9 & 0.0 & Prahl et al. (198 & & Pailler and Bard (2002) \\
\hline MD01-2443 & 37.881 & -10.176 & 292 & & 18 & 17.3 & & 18.0 & -0.7 & Müller et al. (19 & 98) & Martrat et al. (2007) \\
\hline GeoB 7139-2 & -30.2 & -71.9833 & 327 & & 8 & 17.4 & & 18.9 & -1.5 & Prahl et al. (198 & & Kaiser et al. (2008) \\
\hline JR51-GC35 & 66.999 & -17.961 & 420 & & 43 & 7.1 & & 9.4 & -2.3 & Rosell-Melé et a & l. (1995) & Bendle and Rosell-Melé (2007) \\
\hline ODP 977 & 36.032 & -1.955 & 198 & & 26 & 18.1 & & 18.7 & -0.6 & Müller et al. (19 & 98) & Martrat et al. (2004) \\
\hline SO139-74KL & -6.543 & 103.833 & 165 & & 25 & 28.2 & & 27.0 & 1.2 & Conte et al. (20 & & Lückge et al. (2009) \\
\hline MD97-2151 & 8.729 & 109.869 & $15 \mathrm{~s}$ & & 32 & 27.6 & & 26.8 & 0.8 & Pelejero and Gri & malt (1997) & Zhao et al. (2006) \\
\hline GeoB6007 & 30.85 & -10.2683 & 583 & & 70 & 19.0 & & 20.4 & -1.4 & Müller et al. (19 & & Kim et al. (2007) \\
\hline PC17 & 21.358 & -158.19 & 503 & & 35 & 25.6 & & 24.1 & 1.5 & Prahl et al. (198 & & Lee et al. (2001) \\
\hline PC2 & 50.395 & 148.323 & 125 & & 17 & 8 & & 8.1 & -0.1 & Prahl et al. (198 & & Seki et al. (2004) \\
\hline D13882 & 38.634 & -9.454 & 88 & & 72 & 16.1 & & 19.1 & -3.0 & Müller et al. (19 & 98) & Rodrigues et al. (2009) \\
\hline $\mathrm{Mg} / \mathrm{Ca}$-based Holocene SST & ends & & & & & & & & & & & \\
\hline Core name & $\begin{array}{l}\text { Latitude } \\
\left({ }^{\circ} \mathrm{N}\right)\end{array}$ & $\begin{array}{l}\text { Longitude } \\
\left({ }^{\circ} \mathrm{E}\right)\end{array}$ & $\begin{array}{l}\text { Water depth } \\
\text { (m) }\end{array}$ & $\begin{array}{l}\text { Mear } \\
\text { sedin } \\
\text { rate }\end{array}$ & $\begin{array}{l}\text { olocene } \\
\text { tation } \\
\left.\mathrm{ka}^{-1}\right)\end{array}$ & $\begin{array}{l}\text { coretop } \\
\text { SST } \\
\left({ }^{\circ} \mathrm{C}\right)\end{array}$ & $\begin{array}{l}10 \text { ka SST } \\
\left({ }^{\circ} \mathrm{C}\right)\end{array}$ & $\begin{array}{l}\text { Holocene } \\
\text { SST trend } \\
\left({ }^{\circ} \mathrm{C}\right)\end{array}$ & $\mathrm{Mg} / \mathrm{Ca}$ cal & tion & species & Reference \\
\hline MD03-2707 & 2.502 & 9.395 & 1295 & 54 & & 25.5 & 27.1 & -1.6 & Dekens et & 2002) & G. ruber (pink) & Weldeab et al. (2007a) \\
\hline GeoB 4905-4 & 2.5 & 9.39 & 1328 & 20 & & 26.2 & 26.4 & -0.2 & Anand et & 2003) & G. ruber (pink) & Weldeab et al. (2007b) \\
\hline GeoB3129-3911 & -4.613 & -36.637 & 830 & 19 & & 27.1 & 27.3 & -0.2 & Anand et & 2003) & G. ruber (white) & Weldeab et al. (2006) \\
\hline V21-30 & -1.217 & -89.683 & 617 & 11 & & 22.4 & 21.8 & 0.6 & Nürnberg & 1. (1996) & G. sacculifer & Koutavas et al. (2002) \\
\hline PL07-39PC & 10.7 & -65.942 & 790 & 27 & & 26.7 & 26.9 & -0.2 & Dekens et & $2002)$ & G. ruber (white) & Lea et al. (2003) \\
\hline MD98-2181 & 6.3 & 125.83 & 2114 & 85 & & 29.1 & 29.9 & -0.8 & Nürnberg & l. (1996) & G. ruber (white) & Stott et al. (2004) \\
\hline MD98-2176 & -5.003 & 133.445 & 2382 & 71 & & 28.7 & 29.0 & -0.3 & Nürnberg & 1. (1996) & G. ruber (white) & Stott et al. (2004) \\
\hline MD98-2170 & -10.592 & 125.388 & 832 & 28 & & 29.4 & 30.2 & -0.8 & Nürnberg & 1. (1996) & G. ruber (white) & Stott et al. (2004) \\
\hline ODP1242/ME0005A-43JC & 7.856 & -83.608 & 1366 & $\sim 10$ & & 26.6 & 26.4 & 0.2 & Anand et & 2003) & G. ruber (white) & Benway et al. (2006) \\
\hline ODP1084B & -25.514 & 13.278 & 1992 & 11 & & 13.3 & 14.2 & -0.9 & Mashiotta & 1. (1999) & G. bulloides & Farmer et al. (2005) \\
\hline MD98-2162 & -4.689 & 117.903 & 1855 & 63 & & 29.2 & 29 & 0.2 & Hastings $e$ & $(2001)$ & G. ruber & Visser et al. (2003) \\
\hline BOFS $31 \mathrm{~K}$ & 19 & -20.167 & 3300 & 2 & & 17.9 & 17.8 & 0.1 & Elderfield & Ganssen (2000) & $\begin{array}{l}\text { G. ruber }+G \text {. } \\
\text { bulloides }\end{array}$ & Elderfield and Ganssen (2000) \\
\hline ODP Site 984 & 61 & -25 & 1648 & 27 & & 7.6 & 6.9 & 0.7 & von Lange & tal. (2005) & N. pachyderma (d) & ) Came et al. (2007) \\
\hline A7 & 27.82 & 126.98 & 1264 & 15 & & 26.6 & 26.5 & 0.1 & Hastings e & (2001) & G. ruber & Sun et al. (2005) \\
\hline ODP 1240 & 0.022 & -86.446 & 2921 & 10 & & 24.9 & 25.6 & -0.7 & Dekens et & $(2002)$ & G. ruber & Pena et al. (2008) \\
\hline MD99-2155 & 57.433 & -27.9 & 2620 & 146 & & 11.9 & 9.5 & 2.4 & Elderfield & Ganssen (2000) & G. bulloides & Farmer et al. (2008) \\
\hline MD02-2575 & 29.02 & -87.118 & 847 & 19 & & 25.2 & 26.5 & -1.3 & Anand et & 2003) & G. ruber & Nürnberg et al. (2008) \\
\hline TR163-22 & 0.515 & -92.398 & 2830 & 8 & & 24.4 & 24.8 & -0.4 & Dekens et & (2002) & G. ruber & Lea et al. (2006) \\
\hline OCE326-GGC26 & 43.489 & -54.867 & 3975 & 36 & & 14.1 & 14.9 & -0.8 & Elderfield & Ganssen (2000) & G. bulloides & Keigwin et al. (2005) \\
\hline MD98-2165 & -9.649 & 118.338 & 2100 & 52 & & 28.4 & 26.8 & 1.6 & Dekens et & (2002) & G. ruber & Levi et al. (2007) \\
\hline TR163-19 & 2.258 & -90.952 & 2348 & 3 & & 26 & 25.9 & 0.1 & Lea et al. ( & & G. ruber & Lea et al. (2000) \\
\hline MD97-2120 & -45.534 & 174.931 & 1210 & 15 & & 11.7 & 12.6 & -0.9 & Mashiotta & al. (1999) & G. bulloides & Pahnke et al. (2003) \\
\hline MD01-2378 & -13.082 & 121,788 & 1783 & 19 & & 28 & 28.7 & -0.7 & Anand et & 2003) & G. ruber & Xu et al. (2008) \\
\hline RAPID-12-1 K & 62.09 & -17.82 & 1938 & 34 & & 10.8 & 11.7 & -0.9 & Thornalles & al. (2009) & G. bulloides & Thornalley et al. (2009) \\
\hline MD01-2390 & 6.635 & 113.409 & 1545 & 30 & & 27.6 & 28.2 & -0.6 & Dekens et & $(2002)$ & G. ruber s.s. & Steinke et al. (2008) \\
\hline
\end{tabular}




\section{Holocene-Eemian SST trends comparison}

\begin{tabular}{|c|c|c|c|c|c|c|c|c|c|c|c|c|}
\hline $\begin{array}{l}\text { Core } \\
\text { name }\end{array}$ & $\begin{array}{l}\text { Latitude } \\
\left({ }^{\circ} \mathrm{N}\right)\end{array}$ & $\begin{array}{l}\text { Longitude } \\
\left({ }^{\circ} \mathrm{E}\right)\end{array}$ & $\begin{array}{l}\text { Water depth } \\
(\mathrm{m})\end{array}$ & $\begin{array}{l}\text { coretop SST } \\
\left({ }^{\circ} \mathrm{C}\right)\end{array}$ & $\begin{array}{l}10 \text { ka SST } \\
\left({ }^{\circ} \mathrm{C}\right)\end{array}$ & $\begin{array}{l}\text { Holocene SST } \\
\text { trend }\left({ }^{\circ} \mathrm{C}\right)\end{array}$ & $\begin{array}{l}115 \text { ka SST } \\
\left({ }^{\circ} \mathrm{C}\right)\end{array}$ & $\begin{array}{l}126 \text { ka SST } \\
\left({ }^{\circ} \mathrm{C}\right)\end{array}$ & $\begin{array}{l}\text { Eemian } \\
\text { SST } \\
\text { trend } \\
\left({ }^{\circ} \mathrm{C}\right)\end{array}$ & Calibration & Method & Reference \\
\hline \multicolumn{13}{|c|}{ Eastern equatorial Pacific } \\
\hline $\begin{array}{l}\text { TR163- } \\
22\end{array}$ & 0.515 & -92.398 & 2830 & 24.4 & 24.8 & -0.40 & 24.7 & 26.7 & -2 & Dekens et al. (2002) & $\mathrm{Mg} / \mathrm{Ca}$ on G. ruber & Lea et al. (2006) \\
\hline \multicolumn{13}{|c|}{ Western equatorial Pacific } \\
\hline $\begin{array}{l}\text { MD98- } \\
2162\end{array}$ & -4.689 & 117.903 & 1855 & 29.2 & 29 & 0.20 & 28 & 29.3 & -1.3 & Hastings et al. (2001) & $\mathrm{Mg} / \mathrm{Ca}$ on G. ruber & Visser et al. (2003) \\
\hline \multicolumn{13}{|c|}{ Western equatorial Atlantic } \\
\hline $\begin{array}{l}\text { ODP } \\
\quad 1002 C\end{array}$ & 10.7122 & -65.1697 & 893 & 24.8 & 24.8 & 0.0 & 26.5 & 25.7 & 0.8 & Prahl et al., 1988 & Alkenone & Herbert \& Schuffert (2000) \\
\hline \multicolumn{13}{|c|}{ North Atlantic } \\
\hline ODP 977 & 36.032 & -1.955 & 1984 & 18.1 & 18.7 & -0.6 & 18.1 & 20.7 & -2.6 & Müller et al. (1998) & Alkenone & Martrat et al. (2004) \\
\hline
\end{tabular}

Prahl and Wakeham $(1987): \mathrm{T}\left({ }^{\circ} \mathrm{C}\right)=(\mathrm{UK} 37+0.11) / 0.04$

Müller et al. $(1998): \mathrm{T}\left({ }^{\circ} \mathrm{C}\right)=\left(\mathrm{UK}^{\prime} 37-0.044\right) / 0.033$.

Prahl et al. $(1988): \mathrm{T}\left({ }^{\circ} \mathrm{C}\right)=\left(\mathrm{UK}^{\prime} 37-0.039\right) / 0.034$.
Sonzogni et al. $(1997): \mathrm{T}\left({ }^{\circ} \mathrm{C}\right)=\left(\mathrm{UKK}^{\prime} 37-0.317\right) / 0.023$

Sonzogni et al. $(1997): \mathrm{T}\left({ }^{\circ} \mathrm{C}\right)=(\mathrm{UK} 37-0.317) / 0.023$.
Pelejero and Grimalt $(1997): \mathrm{T}\left({ }^{\circ} \mathrm{C}\right)=\left(\mathrm{UK}^{\prime} 37-0.092\right) / 0.031$

Pelejero and Grimalt $(1997): \mathrm{T}\left({ }^{\circ} \mathrm{C}\right)=\left(\mathrm{UK}^{\prime} 37-0.092\right) / 0.031$
Rosell-Melé et al. $(1995): \mathrm{T}\left({ }^{\circ} \mathrm{C}\right)=(\mathrm{UK} 37-0.093) / 0.03$.

Conte et al. $(2006): \mathrm{T}\left({ }^{\circ} \mathrm{C}\right)=-0.957+\left(54.293 \times \mathrm{Uk}^{\prime} 37\right)-\left(52.894 \times\left(\mathrm{Uk}^{\prime} 37\right)^{2}\right)+\left(28.321 \times\left(\mathrm{Uk}^{\prime} 37\right)^{3}\right)$

Lea et al. (2000): $\mathrm{Mg} / \mathrm{Ca}=0.3 \exp (0.089 \mathrm{~T})$ (core-top calibration).

Dekens et al. (2002): $\mathrm{Mg} / \mathrm{Ca}=0.38 \exp (0.09 \mathrm{~T})$ (core-top calibration).

Anand et al. (2003): $\mathrm{Mg} / \mathrm{Ca}=0.38 \exp (0.09 \mathrm{~T})$ (sediment trap calibration).

Nürnberg et al. (1996): $\mathrm{Mg} / \mathrm{Ca}=0.38 \exp (0.091 \mathrm{~T})$ (culture experiments).

Mashiotta et al. (1999): $\mathrm{Mg} / \mathrm{Ca}=0.474 \exp (0.107 \mathrm{~T})$ (culture experiments)

Hastings et al. (2001): $\mathrm{Mg} / \mathrm{Ca}=0.38 \exp (0.089 \mathrm{~T})$ (core-top calibration).

von Langen et al. (2005): $\mathrm{Mg} / \mathrm{Ca}=0.51 \exp (0.1 \mathrm{~T})$ (culture experiments on $\mathrm{N}$. pachyderma (d)).

Elderfield and Ganssen (2000): $\mathrm{Mg} / \mathrm{Ca}=0.52 \exp (0.1 \mathrm{~T})$ (core tops).

Thornalley et al. (2009): $\mathrm{Mg} / \mathrm{Ca}=0.794 \exp (0.1 \mathrm{~T})$ (core tops). 
error of alkenone temperature estimates is about $1{ }^{\circ} \mathrm{C}$. Different alkenone unsaturation indices (Uk37 or $\mathrm{Uk}^{\prime} 37$ ) and calibrations have been applied for each alkenone SST record (Table 1 ), but this issue does not affect the main conclusions we report here, i.e. the mean Holocene sign of SST change.

The $\mathrm{Mg} / \mathrm{Ca}$ ratio measured on surface-dwelling planktonic foraminifera is a well-established SST proxy that has been internationally calibrated by 25 laboratories (Rosenthal et al., 2004; Greaves et al., 2008). Systematic biases owing to, e.g., ecological behaviour of planktonic foraminifera (Regenberg et al., 2009), local hydrologic characteristics such as calcite saturation levels at depth (Dekens et al., 2002), and different cleaning protocols used to remove the coating of Mg-rich contaminant phases (Rosenthal et al., 2004) have led to a wide range of calibration equations to convert $\mathrm{Mg} / \mathrm{Ca}$ into temperature. As for the alkenones results, we report the $\mathrm{Mg} / \mathrm{Ca}$-based SST data as they were estimated in the original publications. We are aware that this strategy can at least partly contribute to heterogeneities among records recognized at the regional scale for $\mathrm{Mg} / \mathrm{Ca}$-based Holocene SST evolutions (see discussion in Chapter 3). However, we believe that this method is best for extracting Holocene SSTs at a global scale since it accounts for local hydrologic or sedimentary specificities at coring sites. Additionally we mainly focus on SST trends, a parameter not influenced by the choice of the calibration equation.

All of the data are presented using the original chronologies. While almost all of the Holocene records were dated by radiocarbon as accurately as possible, the Eemian dating uncertainties are much larger than those for the Holocene. For the purpose of this study we had no reason to change the age models from the original publications; yet it is clear that the dating strategy may complicate the Holocene-Eemian comparison.

The Holocene datasets presented in this study will be archived online at the PANGAEA website (http://www.pangaea.de/Projects/ GHOST).

\section{Results and discussion}

\subsection{Alkenone-derived SST trends during the Holocene}

From the former version of the GHOST database, three main general conclusions were drawn from the long-term Holocene SST evolution as follows: (1) a cooling occurred in the Northeast Atlantic, (2) a warming occurred in the North Pacific, and (3) a warming occurred at low latitudes (Rimbu et al., 2003, 2004; Kim et al., 2004; Lorenz et al., 2006). While no significant increase in the amount of available data from the northern Pacific has occurred during the last few years, calculated SST trends in the North Atlantic and at low latitudes were largely confirmed with new alkenone SST records (Fig. 1).

In other parts of the ocean, the western North Atlantic was better constrained and appeared to be the region that recorded the most prominent SST drop in the database, with a SST decrease of up to $7^{\circ} \mathrm{C}$ over the Holocene (Sachs, 2007, Fig. 1). New low-latitude records from the eastern and western Atlantic and from the eastern Pacific confirmed previous conclusions implying a warming at low latitudes over the Holocene, regardless of oceanic basin and/or the hemisphere (Fig. 1). Alkenone SST records available for the Southern Ocean now suggest that the Holocene experienced a cooling (Fig. 1). This result confirms theoretical results predicted from quasi-transient climate simulations that still remained to be verified with data from the southern hemisphere (e.g. Lorenz et al., 2006). Taken together, these results indicate that alkenone-based SST records reflect regional to basin-scale trends (Fig. 1), but a question remains as to whether this method is more representative of a mean-annual temperature signal or to a certain season that may even have changed during the course of an interglacial.

\section{2. $\mathrm{Mg} / \mathrm{Ca}$-derived SST trends during the Holocene}

Despite recent culture studies for planktonic foraminifera that have demonstrated that the salinity significantly influences the $\mathrm{Mg} / \mathrm{Ca}$ measured on foraminifera tests (Kisakurek et al., 2008), the $\mathrm{Mg} / \mathrm{Ca}$ signal from marine sediments has been considered at first order as dependent on the temperature of the waters in which the planktonic foraminifera tests were calcified (Nürnberg et al., 1996). Complications arise when species-specific ecological behaviour is considered, although it also provides the opportunity to further investigate temperature changes across a wide range of foraminifera growth seasons and water depths (Elderfield and Ganssen, 2000).

Holocene $\mathrm{Mg} / \mathrm{Ca}$-derived SST trends are generally of a lower amplitude than the alkenone-derived SST trends (Fig. 2). The point-to-point scatter of $\mathrm{Mg} / \mathrm{Ca}$-derived SST values is larger in the individual records than in the alkenone-derived records, leading to an apparently more "noisy" SST signal derived from the $\mathrm{Mg} / \mathrm{Ca}$ as compared to alkenone SST values (see e.g. Fig. 3). One possible explanation for this observation may be linked to the method since $\mathrm{Mg} / \mathrm{Ca}$ values are derived from a small subset of foraminifera that represent orders of magnitude lower amounts of the planktonic organisms contained in a sample compared to alkenones extracted from a certain amount of

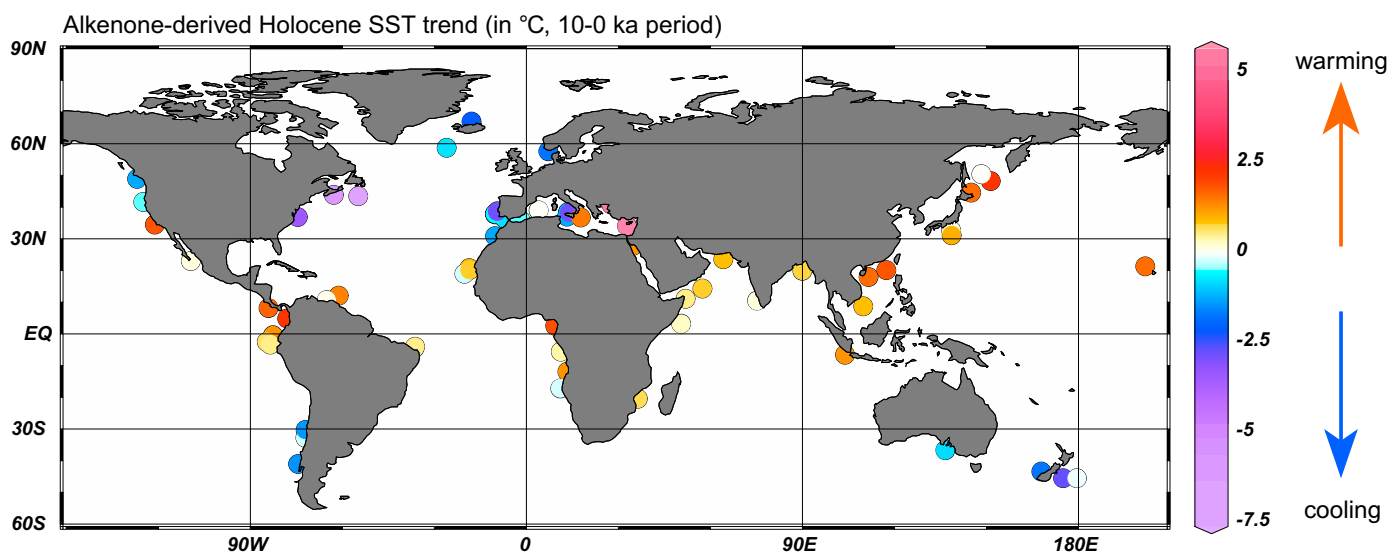

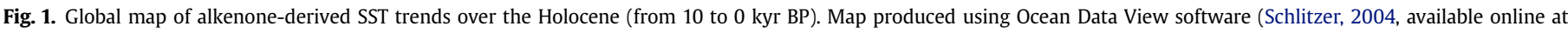
http://odv.awi.de/). (For interpretation of the references to color in this figure legend, the reader is referred to the web version of this article). 


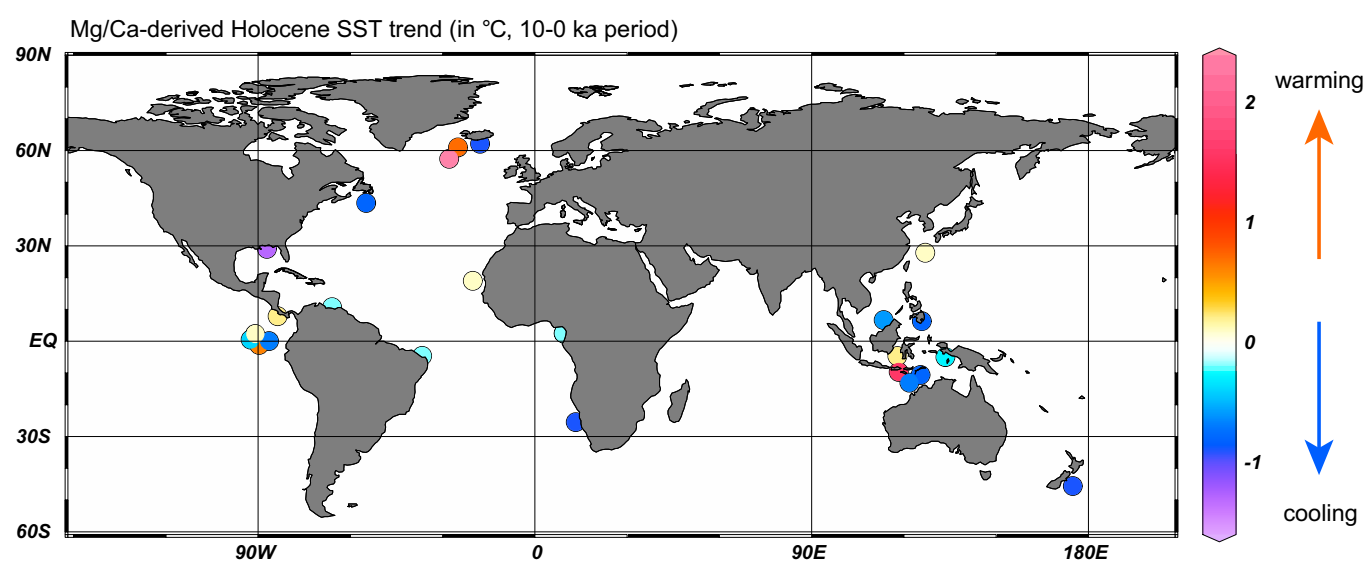

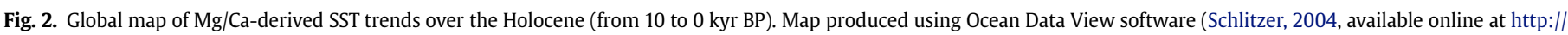
odv.awi.de/). (For interpretation of the references to color in this figure legend, the reader is referred to the web version of this article).

sediment volume. Secondly, lateral transport through oceanic currents (Ohkouchi et al., 2002) or bioturbation (Bard, 2001) may have tended to smooth the SST signal regionally or downcore, respectively, two factors that are probably more effective for alkenones than for planktonic foraminifera. Thirdly, some intervals may have been affected by dissolution, one mechanism that artificially lowers the $\mathrm{Mg} / \mathrm{Ca}$ (Regenberg et al., 2006).

One easy way to check for the potential effect of dissolution resides in weighting the foraminifera prior to foraminifera cleaning, or eventually, measuring the sedimentary calcium carbonate content downcore. Unfortunately, not all studies report foraminiferal weights and explicitly use this information to control a potential impact of dissolution (see e.g. discussion in Lea et al. (2006) and Tachikawa et al. (2008)) while the calcium carbonate content may also be linked to changes in calcium carbonate productivity itself, so that it remains difficult to assess whether dissolution is a bias that may have affected $\mathrm{Mg} / \mathrm{Ca}$-derived SSTs globally or regionally. Alternatively, marine sediment core depth may be another indication for the likelihood of the dissolution effect on $\mathrm{Mg} / \mathrm{Ca}$ thermometry since it may influence sediment cores deeper than $\sim 2000 \mathrm{~m}$.

Unlike alkenone-derived records, $\mathrm{Mg} / \mathrm{Ca}$ SST trends are rather equivocal at the regional scale (Fig. 2). This observation may somehow reflect the lower spatial resolution of $\mathrm{Mg} / \mathrm{Ca}$ data as compared to the alkenone-derived SST dataset. From the $\mathrm{Mg} / \mathrm{Ca}$ SST records presented here it seems that improving the spatial coverage will help to clarify the general picture of Holocene SST evolution on the regional or basin-wide scale. Yet it remains difficult to assess if $\mathrm{Mg} / \mathrm{Ca}$ first-order SST trends capture regional-scale features or very small-scale hydrographic conditions. The most puzzling result is likely the lack of reproducibility of the basin-wide SST picture drawn by alkenones in individual $\mathrm{Mg} / \mathrm{Ca}$-based records. Perhaps the difference between Holocene SST as viewed by alkenones (Fig. 1) and by $\mathrm{Mg} / \mathrm{Ca}$ (Fig. 2) that often point to proxy-dependent divergent SST trends in many parts of the ocean could potentially be explained if the two methods represent different hydrographic or seasonal conditions for a certain region.

\subsection{A detailed comparison of alkenone and $\mathrm{Mg} / \mathrm{Ca}$-based SST evolution}

Fig. 3 presents the original alkenone and $\mathrm{Mg} / \mathrm{Ca}$ SST evolution for some regions, namely in the EEP, the WEA, the Indonesian archipelago, as well as in the North Atlantic.

In the EEP, the North-South SST gradient is reasonably well captured by both alkenone unsaturation and $\mathrm{Mg} / \mathrm{Ca}$ ratios.
Alkenone-derived SST records over the last $10 \mathrm{ka}$ are all marked by a warming of $\sim 0.5-2{ }^{\circ} \mathrm{C}$, regardless of modern-day hydrological conditions (Fig. 3a). Holocene $\mathrm{Mg} / \mathrm{Ca}$ temperature changes locally are quite different and variable, but none among the seven $\mathrm{Mg} / \mathrm{Ca}$ records available for the EEP have exhibited monotonous warming during the Holocene as was the case for alkenone SST records (Fig. 3a). Analogous divergent trends between the two SST proxies have already been reported for the EEP during the millennial-scale climate fluctuations that punctuated the last deglaciation (Mix, 2006; Koutavas and Sachs, 2008). To explain alkenone-derived SST trends in the EEP that imply monotonous warming regardless of the local hydrologic particularities, changes in low-latitude insolation can be invoked if one assumes that alkenones preferentially captured the boreal winter season (Fig. 3a). This assumption has the advantage explaining the similarity between alkenone-derived SST trends through a systematic signal formation during a narrow seasonal time interval in the course of a year, as depicted in Huybers and Wunsch (2003). This hypothesis is in broad agreement with modern seasonal changes in primary productivity in the EEP (Pennington et al., 2006). On the other hand, the $\mathrm{Mg} / \mathrm{Ca}$-derived Holocene SST evolution in the EEP that was not marked by a general warming can be explained by a systematic sampling of the other seasons. $\mathrm{Mg} / \mathrm{Ca}$ may either have marginally imprinted the boreal summer insolation changes - in agreement with present-day Globigerinoides ruber fluxes in the Panama Basin (Thunell et al., 1983), or may reflect more meanannual SST changes at low latitudes as smoother SST changes compared to the alkenone-based records suggest. However, a closer look to the ensemble of $\mathrm{Mg} / \mathrm{Ca}$-derived SST records revealed much more heterogeneity for Holocene temperature trends than for alkenone-derived SST records, making the $\mathrm{Mg} / \mathrm{Ca}$ ratios more complicated to interpret in terms of the overall temperature trends (Fig. 3a). Therefore some of the features in $\mathrm{Mg} / \mathrm{Ca}$-derived SST records are linked to complex combinations of quite different ecological behaviours of planktonic foraminifera (see chapter 3.5.2).

Also, differential partial planktonic foraminifera test dissolution can have modulated the amplitude of SST changes in this region, which is known to be particularly corrosive (Mekik et al., 2007). For example, an increase in primary productivity over the Holocene would necessarily have increased biologically-mediated calcite dissolution over this time period, potentially leading to decreased $\mathrm{Mg} / \mathrm{Ca}$-derived SST estimations. Surrounding the equator, this may explain why the deepest record of Pena et al. (2008) was also marked by the sharpest SST trend as compared to shallower sites (Fig. 3a).

The same picture of different SST changes highlighted by the two methods can also be observed in the WEA (Fig. 3b). While alkenone- 
Holocene SST records $\left({ }^{\circ} \mathrm{C}\right)$

\section{Present-day SST $\left({ }^{\circ} \mathrm{C}\right)$}
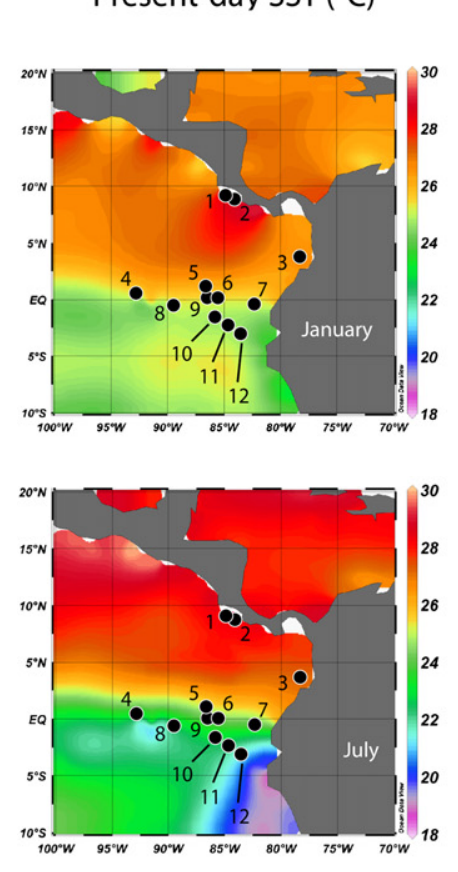

Present-day SST $\left({ }^{\circ} \mathrm{C}\right)$

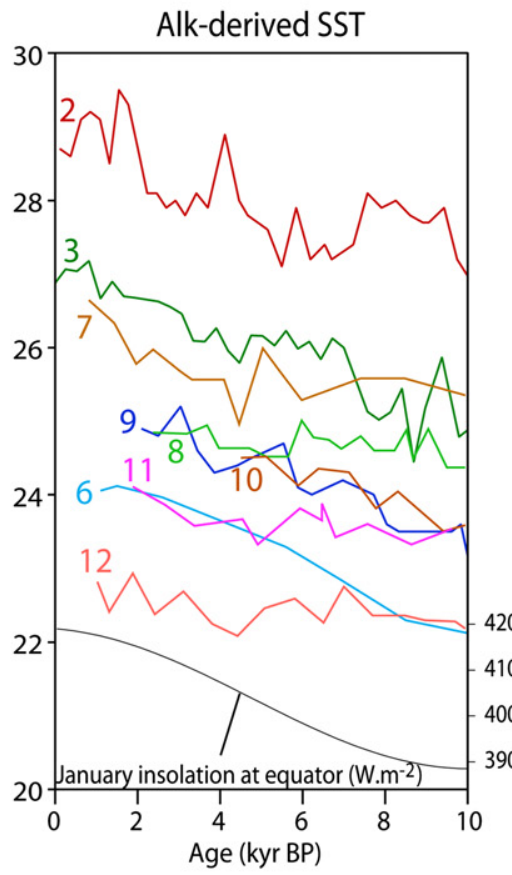

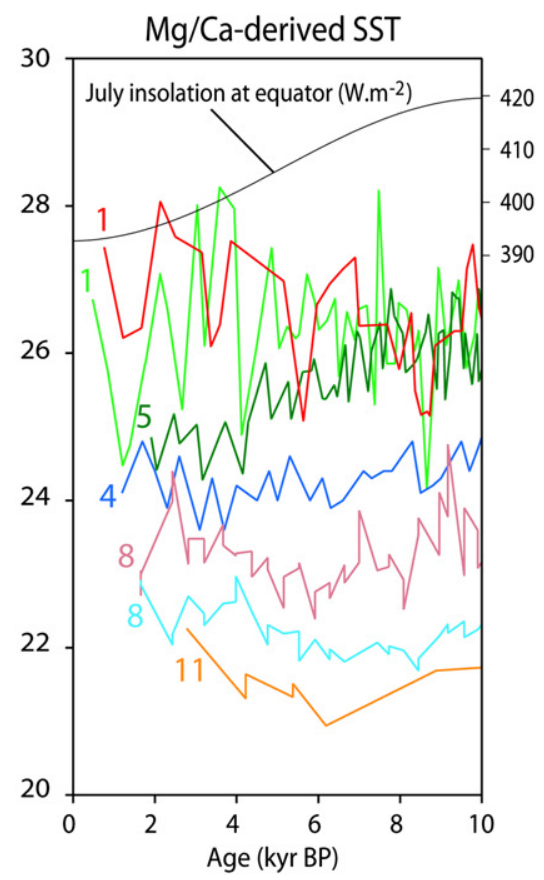

Holocene SST records $\left({ }^{\circ} \mathrm{C}\right)$
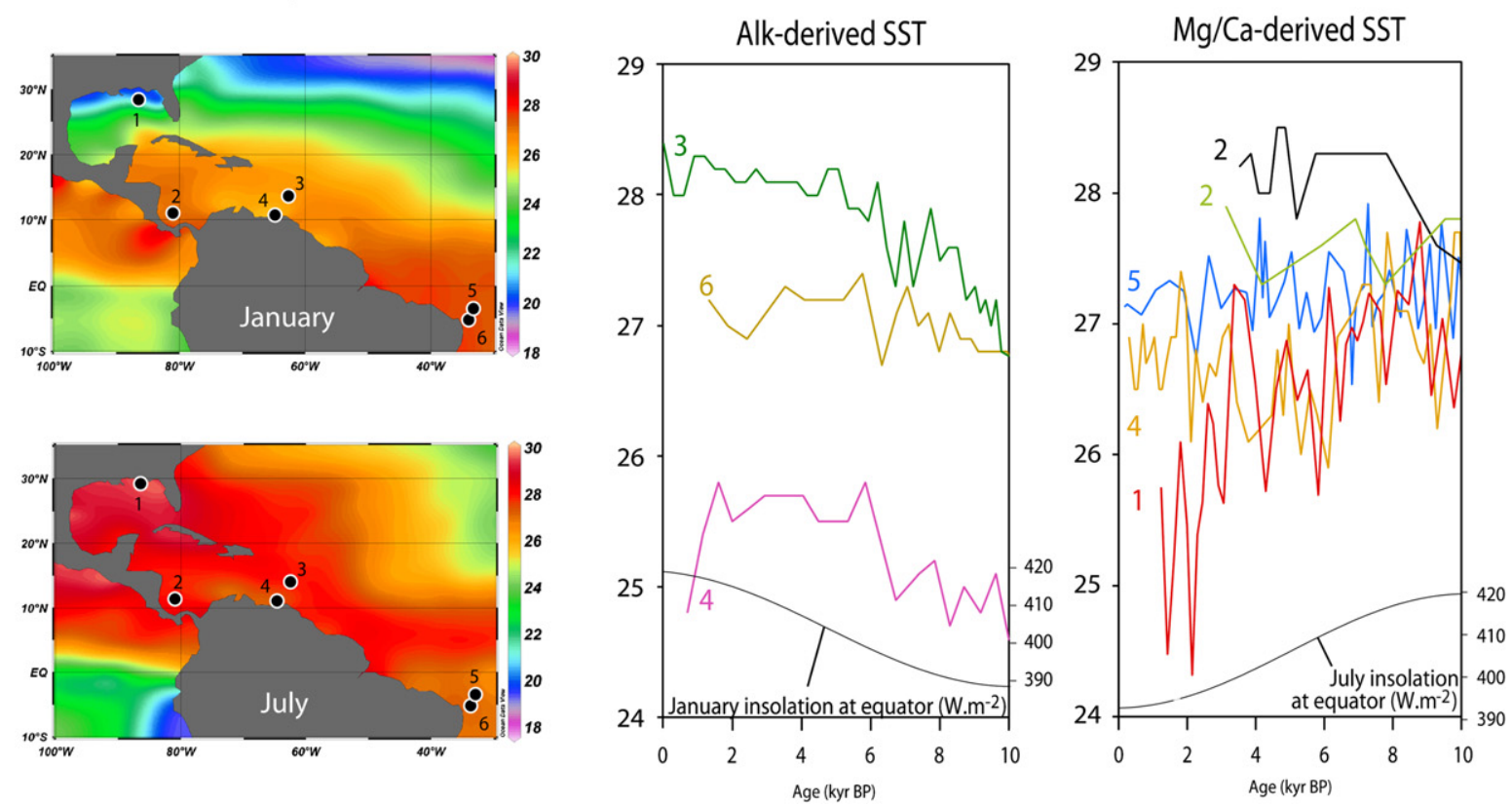

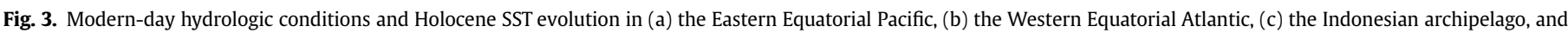

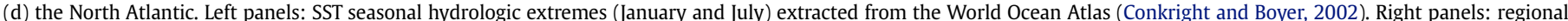

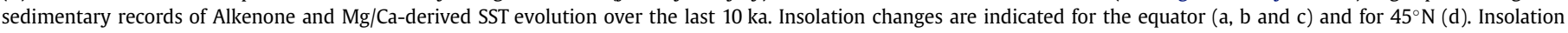

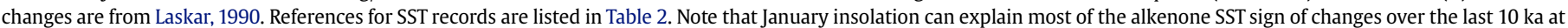

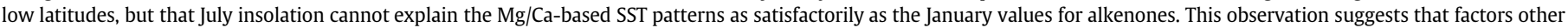

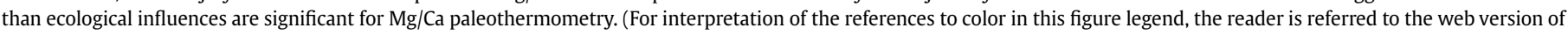
this article).

derived SST records indicate a warming over the Holocene, $\mathrm{Mg} / \mathrm{Ca}$ derived SST records indicate either no trend or a cooling trend for the same time period. In particular, the cooling trend as recorded in the $\mathrm{Mg} / \mathrm{Ca}$-derived SST record off of the Mississippi River mouth has been assumed to reflect a summer temperature signal (Nürnberg et al., 2008). Unpublished alkenone results from the same core indicate a warming (Nürnberg and Blanz, personal communication), suggesting a winter-weighted temperature record if the concept of seasonal insolation changes shaping SST records in a different manner as discussed for the EEP are applied to the WEA.

SST records surrounding the Indonesian archipelago are presented in Fig. 3c. Despite low seasonal ranges in modern SSTs, the 
Present-day SST $\left({ }^{\circ} \mathrm{C}\right)$
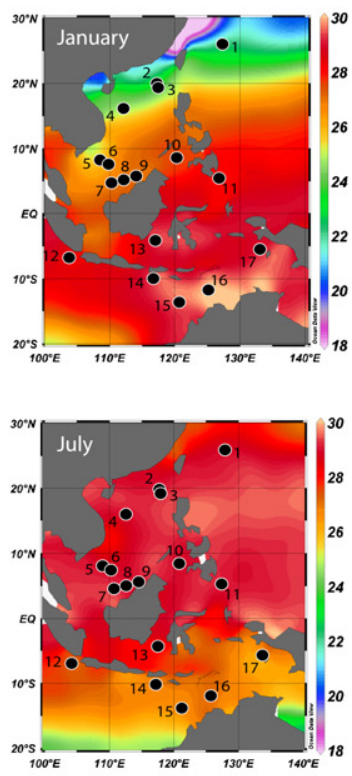

Present-day SST $\left({ }^{\circ} \mathrm{C}\right)$

\section{Holocene SST records $\left({ }^{\circ} \mathrm{C}\right)$}

$\mathrm{Mg} / \mathrm{Ca}$-derived SST (South China Sea)

$\mathrm{Mg} /$ Ca-derived SST

(Indonesian archipelago)

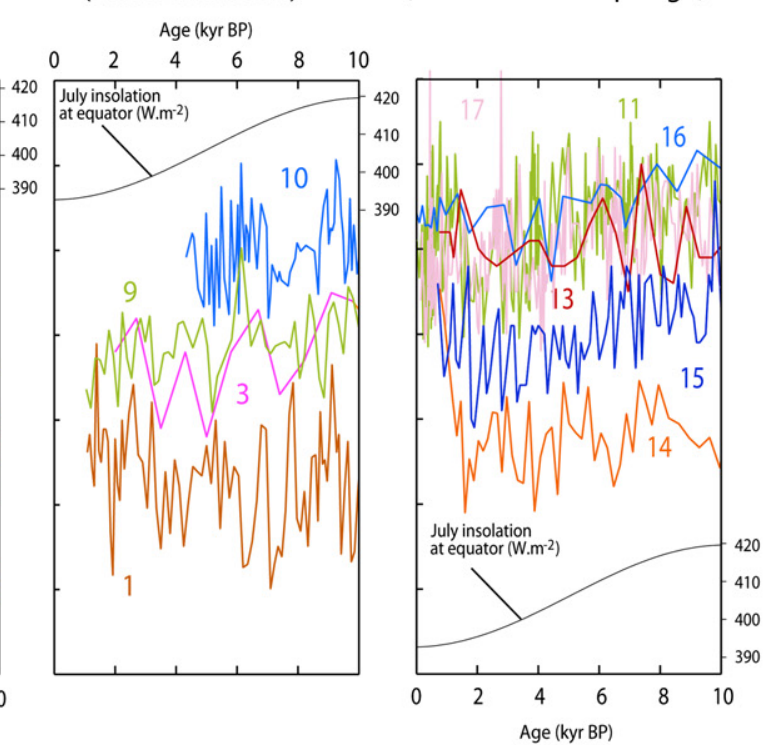

Holocene SST records $\left({ }^{\circ} \mathrm{C}\right)$
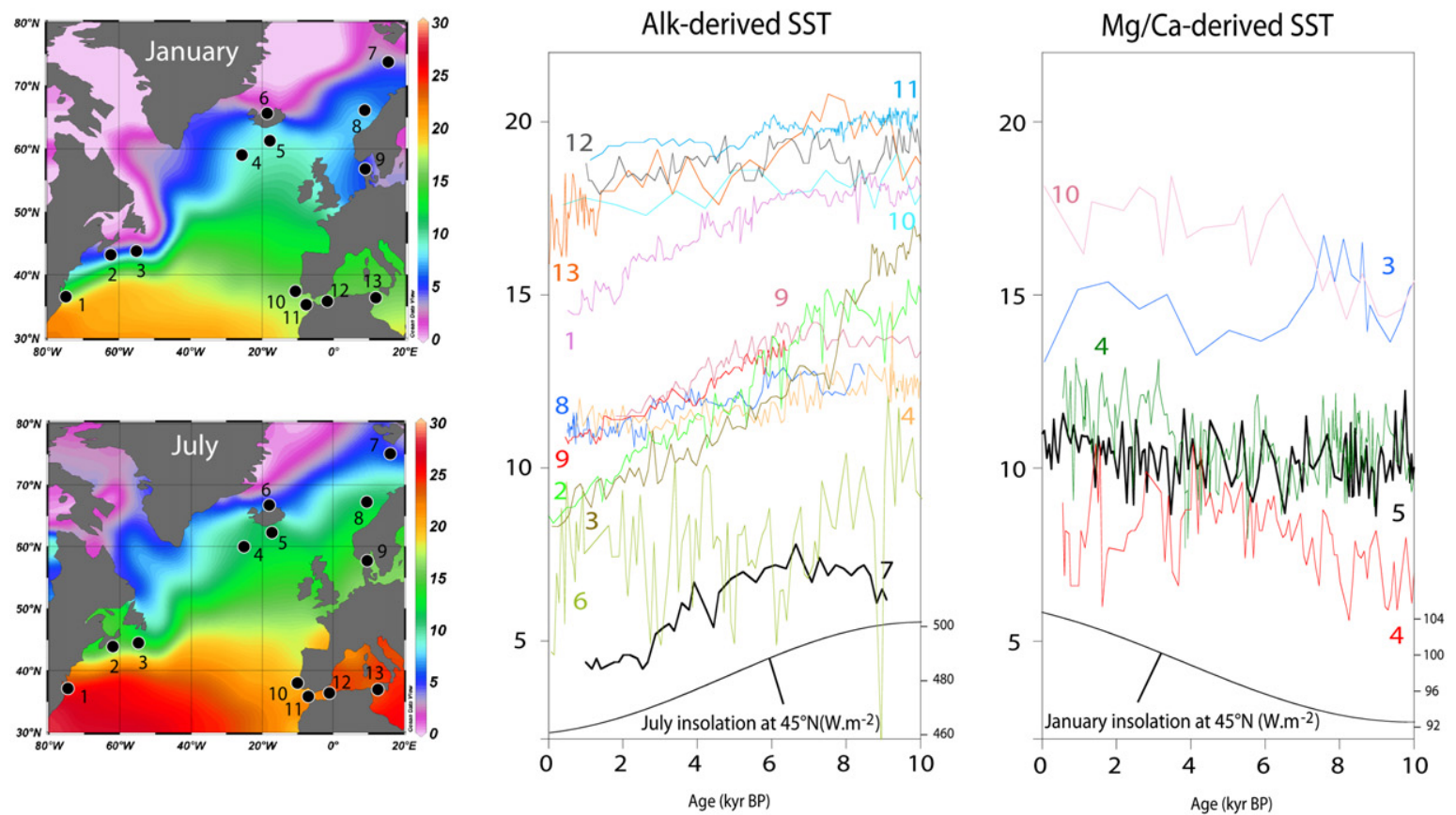

Fig. 3. (continued)

data suggest that a common forcing is still involved in shaping alkenone-based Holocene SST trends in this area. The alkenonederived SST records are mainly from the South China Sea, and all of them seem to be marked by an early Holocene warming followed by a late Holocene stagnation in SST (Fig. 3c). Speleothem records from northern Borneo have revealed a mid-Holocene inflexion in precipitation trends with a comparable timing, likely reflecting a close relationship between Borneo precipitation and SST in adjacent seas (Partin et al., 2007). Possible is that alkenonederived SST and speleothem-based precipitation records, owing to concomitant phytoplankton productivity and regional precipitation, are both driven by spring/fall precessional forcing (Partin et al., 2007). This assumption is in line with studies demonstrating the importance of river discharge for seasonal dynamics of primary productivity in the South China Sea (Chen and Chen, 2006). As for other tropical basins, the $\mathrm{Mg} / \mathrm{Ca}$-derived SST records around the Indonesian archipelago suggest a slight cooling (Stott et al., 2004, Figs. 2 and $3 \mathrm{c}$ ), with the opposite sign of the SST changes related to different proxies that are most evident during the early Holocene time period. Again, this observation can result 
from proxy sensitivity to different seasons that were not impacted by the same insolation forcing over the Holocene.

In the North Atlantic, a cooling of SST is common in almost all of the mid- to high-latitude alkenone-derived SST records available in the literature, while the few $\mathrm{Mg} / \mathrm{Ca}$ records available either show no trend or a slight warming trend during the Holocene (Fig. 3d). The Holocene cooling trend, as revealed by alkenone paleothermometry for the North Atlantic, is of the opposite sign in low-latitude SST records. Thus far, the difference between high and low latitudes has been explained by the overall Holocene insolation change that tends to warm the tropical ocean toward the end of the Holocene, while the northern high latitudes do not experience a strong boreal winter season warming but rather a strong summer season cooling (e.g. Lorenz et al. 2006). However, if this assumption is correct, Holocene SST trends should reveal a warming in southern high latitudes since the austral summer insolation is increasing during the Holocene, which is not observed for either of the two methods (Figs. 1 and 2). Again, such discrepancies are likely embedded in proxy sensitivities to seasonal effects on temperature signal formation. Those deviations remain to be better understood by putting special emphasis on (1) a better constraint for the significance of SST records derived from complex planktonic foraminifera ecological behaviour (see discussion in Hillaire-Marcel and de Vernal, 2008; Fraile et al., 2009), and on (2) high-latitude alkenone-derived SSTs that may be globally biased toward the spring or the summer months (see discussion in Prahl et al., 2010).

\subsection{Evidence from the penultimate interglacial time period}

If insolation changes are the main forcing for the proxydependent diverging SST evolution we have described for the Holocene, then the penultimate interglacial period (i.e. the Eemian), which is marked by stronger insolation changes due to larger magnitude in the precessional variance, should reveal similar SST trends for each method in the Holocene and in the Eemian, but with higher amplitude in SST change during the Eemian. A first test of this hypothesis is to compare Holocene SST records with a corresponding dataset for the Eemian interval.
Unfortunately, the Eemian period is much less documented with appropriate SST records than the Holocene because of the scarcity of long sediment cores that penetrated into Eemian sequences at sites with sufficiently high sedimentation rates. In addition, the dating issue is critical since orbital tuning of the benthic isotopic signal may artificially homogenize the temporal relationship between SST signals at different locations. However, the latter problem has only been considered marginally here since it may not influence the interpretations we make for long-term SST trends over the last two interglacial time windows. For the comparison between interglacials we have chosen Eemian SST records from the literature only for the regions we considered for the Holocene in Fig. 3. Accordingly, Fig. 4 presents the SST trends for the 0-14 kyr BP and for the 116-130 kyr BP time intervals. This choice provides good benchmarks at the precessional timescale, namely the 10, 6 and $0 \mathrm{kyr}$ BP time intervals (early, mid and late Holocene) analogous to 126, 122 and $115 \mathrm{kyr}$, respectively, BP at low latitudes (Braconnot et al., 2008), allowing a direct comparison of Holocene and Eemian SSTs in tropical latitudes.

As expected, the EEP, the WEA, the Indonesian archipelago, and the North Atlantic were marked by a similar sign for SST changes but with slightly larger amplitudes for the Eemian than for the Holocene (Fig. 4, Table 1). The opposite signs between high and low latitudes observed in alkenone-derived Holocene SST trends recorded in the Atlantic were found with a slightly increased amplitude in Eemian SST records from the same sedimentary sequence (Fig. 4), although the Holocene trend amplitude calculated for the Cariaco Basin was affected by the last alkenone low SST data point of the Holocene record (Table 2). The tropical Pacific Mg/Ca-derived SST changes also showed a clear cooling during the Eemian while Holocene SST seemed to be almost constant. In the EEP where dissolution is suspected to modulate some of the observed $\mathrm{Mg} / \mathrm{Ca}$-derived SST changes, Eemian SSTs were unlikely to be more extensively affected by dissolution than over the Holocene period, as G. ruber weights and a suite of other proxies for dissolution suggest (Lea et al. 2006). Therefore we interpret these SST observations as reflective of a larger magnitude in seasonal insolation changes during the Eemian, as compared to Holocene values which are hypothesized to have
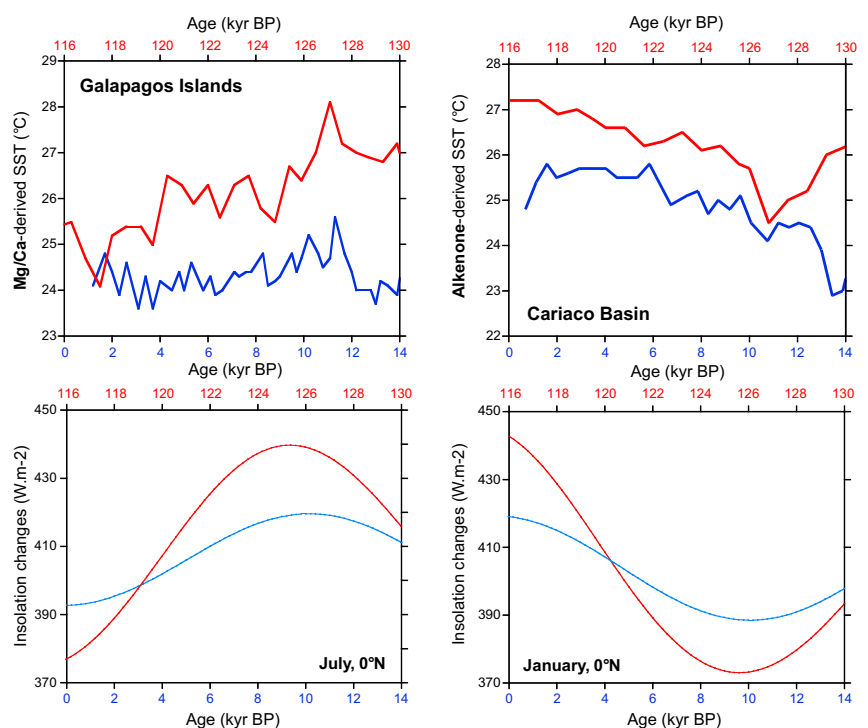
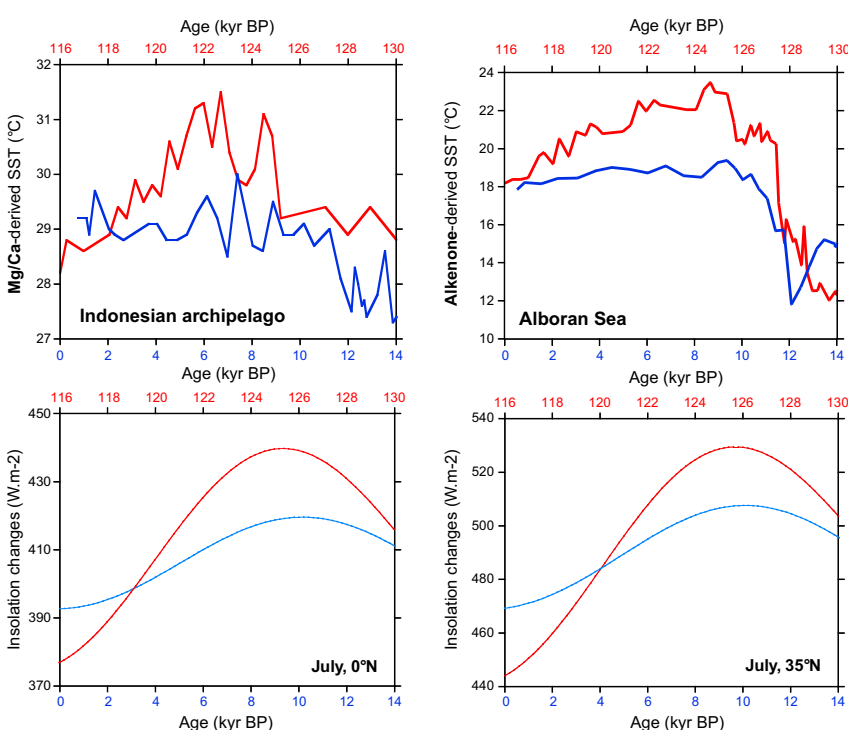

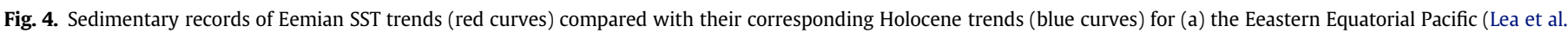

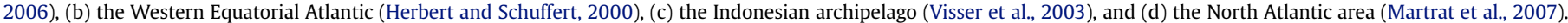

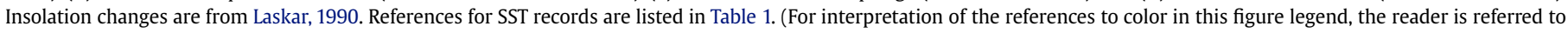
the web version of this article). 
Table 2

References for sedimentary results shown in Fig. 3. See Table 1 for calibration equation.

\begin{tabular}{|c|c|c|c|c|c|c|c|}
\hline \#SST record & Core Name & Method & $\begin{array}{l}\text { Lat. } \\
(N>0)\end{array}$ & $\begin{array}{l}\text { Long. } \\
(E>0)\end{array}$ & Depth (m) & Calibration & Reference \\
\hline \multicolumn{8}{|c|}{ Fig. 3 a: eastern equatorial Pacific } \\
\hline 1 (red curve) & ME0005A-43JC & $\mathrm{Mg} / \mathrm{Ca}$ on $\mathrm{G}$. ruber & 7.856 & -83.608 & 1368 & Anand et al. (2003) & Benway et al. (2006) \\
\hline 1 (green curve) & ODP 1242 & $\mathrm{Mg} / \mathrm{Ca}$ on G. ruber & 7.856 & -83.608 & 1364 & Anand et al. (2003) & Benway et al. (2006) \\
\hline 2 & MD02-2529 & Uk'37 & 8.206 & -84.122 & 1619 & Sonzogni et al. (1997) & Leduc et al. (2007) \\
\hline 3 & KNR176-JPC32 & Uk’37 & 4.847 & -77.963 & 2200 & Prahl et al. (1988) & Pahnke et al. (2007) \\
\hline 4 & TR163-22 & $\mathrm{Mg} / \mathrm{Ca}$ on G. ruber & 0.515 & -92.398 & 2830 & Dekens et al. (2002) & Lea et al. (2006) \\
\hline 5 & ODP1240 & $\mathrm{Mg} / \mathrm{Ca}$ on $\mathrm{G}$. ruber & 0.022 & -86.446 & 2921 & Dekens et al. (2002) & Pena et al. (2008) \\
\hline 6 & Y69-71P & Uk’37 & 0.083 & -86.482 & 2740 & Prahl et al. (1988) & Prahl et al. (2006) \\
\hline 7 & V19-27 & Uk'37 & -0.467 & -82.667 & 1373 & Prahl et al. (1988) & Koutavas and Sachs (2008) \\
\hline 8 (green curve) & V21-30 & Uk'37 & -1.217 & -89.683 & 617 & Prahl et al. (1988) & Koutavas and Sachs (2008) \\
\hline 8 (pink curve) & V21-30 & $\mathrm{Mg} / \mathrm{Ca}$ on G. ruber & -1.217 & -89.683 & 617 & Dekens et al. (2002) & Koutavas et al. (2006) \\
\hline 8 (blue curve) & V21-30 & $\mathrm{Mg} / \mathrm{Ca}$ on $\mathrm{G}$. sacculifer & -1.217 & -89.683 & 617 & Nürnberg et al. (1996) & Koutavas et al. (2002) \\
\hline 9 & ME0005A-24JC & Uk’37 & 1.5 & -86.485 & 2941 & Prahl et al. (1988) & Kienast et al. (2006) \\
\hline 10 & RC11-238 & Uk'37 & -1.517 & -85.817 & 2573 & Prahl et al. (1988) & Koutavas and Sachs (2008) \\
\hline 11 (pink curve) & V19-28 & Uk'37 & -2.51 & -84.650 & 2720 & Prahl et al. (1988) & Koutavas and Sachs (2008) \\
\hline 11 (orange curve) & V19-28 & $\mathrm{Mg} / \mathrm{Ca}$ on G. ruber & -2.51 & -84.650 & 2720 & Dekens et al. (2002) & Koutavas et al. (2006) \\
\hline 12 & V19-30 & Uk'37 & -3.383 & -83.517 & 3091 & Prahl et al. (1988) & Koutavas and Sachs (2008) \\
\hline \multicolumn{8}{|c|}{ Fig. 3b: western equatorial Atlantic } \\
\hline 1 & MD02-2575 & $\mathrm{Mg} / \mathrm{Ca}$ on G. ruber & 29.02 & -87.118 & 847 & Anand et al. (2003) & Nürnberg et al. (2008) \\
\hline 2 (green curve) & VM28-122 & $\mathrm{Mg} / \mathrm{Ca}$ on $\mathrm{G}$. ruber & 11.567 & -78.417 & 3623 & Dekens et al. (2002) & Schmidt et al. (2004) \\
\hline 2 (black curve) & ODP999 & $\mathrm{Mg} / \mathrm{Ca}$ on $\mathrm{G}$. ruber & 12.75 & -78.733 & 2827 & Dekens et al. (2002) & Schmidt et al. (2004) \\
\hline 3 & M35003-4 & Uk'37 & 12.083 & -61.25 & 1299 & Müller et al. (1998) & Rühlemann et al. (1999) \\
\hline 4 (pink curve) & ODP1002 & Uk’37 & 10.712 & -65.17 & 893 & Prahl et al. (1988) & Herbert and Schuffert (2000) \\
\hline 4 (orange curve) & PL07-39PC & $\mathrm{Mg} / \mathrm{Ca}$ on $\mathrm{G}$. ruber & 10.7 & -65.942 & 790 & Dekens et al. (2002) & Lea et al. (2003) \\
\hline 5 & GeoB3129-3911 & $\mathrm{Mg} / \mathrm{Ca}$ on G. ruber & -4.613 & -36.637 & 830 & Anand et al. (2003) & Weldeab et al. (2006) \\
\hline 6 & GeoB 3910-2 & Uk’37 & -4.025 & -36.345 & 2362 & Prahl et al. (1988) & Jaeschke et al. (2007) \\
\hline \multicolumn{8}{|c|}{ Fig. 3c: Indonesian archipelago } \\
\hline 1 & A7 & $\mathrm{Mg} / \mathrm{Ca}$ on $\mathrm{G}$. ruber & 27.82 & 126.98 & 1264 & Hastings et al. (2001) & Sun et al. (2005) \\
\hline 2 & $17940-2$ & Uk'37 & 20.117 & 117.383 & 1727 & Müller et al. (1998) & Pelejero et al. (1999) \\
\hline 3 & ODP 1145 & $\mathrm{Mg} / \mathrm{Ca}$ on G. ruber & 19.583 & 117.633 & 3175 & Dekens et al. (2002)) & Oppo and Sun (2007) \\
\hline 4 & SCS90-36 & Uk’37 & 17.995 & 111.494 & 2050 & Prahl et al. (1988) & Huang et al. (1997) \\
\hline 5 & $18252-3$ & Uk'37 & 9.233 & 109.383 & 1273 & Pelejero and Grimalt (1997) & Kienast et al. (2001) \\
\hline 6 & MD97-2151 & Uk'37 & 8.729 & 109.869 & 1598 & Pelejero and Grimalt (1997) & Zhao et al. (2006) \\
\hline 7 & $18287-3$ & Uk’37 & 5.65 & 110.65 & 598 & Pelejero and Grimalt (1997) & Kienast et al. (2001) \\
\hline 8 & 17964 & Uk'37 & 6.158 & 112.213 & 1556 & Müller et al. (1998) & Pelejero et al. (1999) \\
\hline 9 & MD01-2390 & $\mathrm{Mg} / \mathrm{Ca}$ on G. ruber (s.s.) & 6.635 & 113.409 & 1545 & Dekens et al. (2002) & Steinke et al. (2008) \\
\hline 10 & MD97-2141 & $\mathrm{Mg} / \mathrm{Ca}$ on $\mathrm{G}$. ruber & 8.8 & 121.3 & 3633 & Rosenthal and Lohmann (2002) & Rosenthal et al. (2003) \\
\hline 11 & MD98-2181 & $\mathrm{Mg} / \mathrm{Ca}$ on G. ruber & 6.3 & 125.83 & 2114 & Nürnberg et al. (1996) & Stott et al. (2004) \\
\hline 12 & SO139-74KL & Uk’37 & -6.543 & 103.833 & 1690 & Conte et al. (2006) & Lückge et al. (2009) \\
\hline 13 & MD98-2162 & $\mathrm{Mg} / \mathrm{Ca}$ on $\mathrm{G}$. ruber & -4.689 & 117.903 & 1855 & Hastings et al. (2001) & Visser et al. (2003) \\
\hline 14 & MD98-2165 & $\mathrm{Mg} / \mathrm{Ca}$ on $\mathrm{G}$. ruber & -9.649 & 118.338 & 2100 & Dekens et al. (2002) & Levi et al. (2007) \\
\hline 15 & MD01-2378 & $\mathrm{Mg} / \mathrm{Ca}$ on $\mathrm{G}$. ruber & -13.082 & 121.788 & 1783 & Anand et al. (2003) & Xu et al. (2008) \\
\hline 16 & MD98-2170 & $\mathrm{Mg} / \mathrm{Ca}$ on $\mathrm{G}$. ruber & -10.592 & 125.388 & 832 & Nürnberg et al. (1996) & Stott et al. (2004) \\
\hline 17 & MD98-2176 & $\mathrm{Mg} / \mathrm{Ca}$ on G. ruber & -5.003 & 133.445 & 2382 & Nürnberg et al. (1996) & Stott et al. (2004) \\
\hline \multicolumn{8}{|c|}{ Fig. 3d: north Atlantic } \\
\hline 1 & CH07-98-GGC19 & Uk'37 & 36.867 & -74.567 & 1049 & Prahl et al. (1988) & Sachs (2007) \\
\hline 2 & OCE326-GGC30 & Uk'37 & 43.882 & -62.8 & 250 & Prahl et al. (1988) & Sachs (2007) \\
\hline 3 (brown curve) & OCE326-GGC26 & Uk'37 & 43.483 & -54.867 & 3975 & Prahl et al. (1988) & Sachs (2007) \\
\hline 3 (blue curve) & OCE326-GGC26 & $\mathrm{Mg} / \mathrm{Ca}$ on $\mathrm{G}$. bulloides & 43.483 & -54.867 & 3975 & Elderfield and Ganssen (2000) & Keigwin et al. (2005) \\
\hline 4 (red curve) & ODP Site 984 & $\mathrm{Mg} / \mathrm{Ca}$ on $N$. pachyderma (d) & 61 & -25 & 1648 & von Langen et al. (2005) & Came et al. (2007) \\
\hline 4 (green curve) & MD99-2155 & $\mathrm{Mg} / \mathrm{Ca}$ on $\mathrm{G}$. bulloides & 57.433 & -27.9 & 2620 & Elderfield and Ganssen (2000) & Farmer et al. (2008) \\
\hline 4 (orange curve) & MD952015 & Uk'37 & 58.762 & -25.958 & 2630 & Müller et al. (1998) & Marchal et al. (2002) \\
\hline 5 & RAPID-12-1 K & $\mathrm{Mg} / \mathrm{Ca}$ on $\mathrm{G}$. bulloides & 62.09 & -17.82 & 1938 & Thornalley et al. (2009) & Thornalley et al. (2009) \\
\hline 6 & JR51-GC35 & Uk37 & 66.999 & -17.961 & 420 & Rosell-Melé et al. (1995) & Bendle and Rosell-Melé (2007) \\
\hline 7 & M23258-2 & Uk37 & 74.995 & 13.97 & 1768 & Rosell-Melé et al. (1995) & Marchal et al. (2002) \\
\hline 8 & MD952011 & Uk37 & 66.967 & 7.633 & 1048 & Prahl and Wakeham (1987) & Calvo et al. (2002) \\
\hline 9 (red curve) & IOW 225514 & UK'37 & 57.838 & 8.704 & 420 & Müller et al. (1998) & Emeis et al. (2003a) \\
\hline 9 (pink curve) & IOW 225517 & UK'37 & 57.667 & 7.091 & 293 & Müller et al. (1998) & Emeis et al. (2003a) \\
\hline 10 (blue curve) & SU81-18 & UK'37 & 37.767 & -10.183 & 3135 & Prahl et al. (1988) & Bard et al. (2000) \\
\hline 10 (pink curve) & MD99-2334 & $\mathrm{Mg} / \mathrm{Ca}$ on $\mathrm{G}$. bulloides & 37.8 & -10.166 & 3146 & Elderfield and Ganssen (2000) & Skinner and Elderfield (2005) \\
\hline 11 & GeoB 5901-2 & UK'37 & 36.38 & -7.071 & 574 & Prahl et al. (1988) & Kim et al. (2004) \\
\hline 12 & MD95-2043 & UK’37 & 36.143 & -2.622 & 1841 & Müller et al. (1998) & Cacho et al. (1999) \\
\hline 13 & M40-4-SL78/78MUC8 & UK’37 & 37.036 & 13.19 & 470 & Müller et al. (1998) & Emeis and Dawson (2003) \\
\hline
\end{tabular}


shaped the interglacial SST records. The observations agree with the interpretation we have proposed to explain proxy-dependent divergent SST trends over the Holocene, that have been suggested as driven by distinct seasonal influences for insolation changes on the signal ultimately recorded by different planktonic organisms. However, the observations should be confirmed by new highresolution $\mathrm{Mg} / \mathrm{Ca}$ records derived from marine sediments retrieved at shallower depths and with the high-quality monitoring of calcite dissolution as presented in Lea et al. (2006) and in Tachikawa et al. (2008).

\subsection{Implications and new perspectives determined from proxy- related divergent SST trends during the Holocene}

While the low-latitude warming vs. the high-latitude cooling trends observed in the alkenone-derived SST records are a robust feature of the Holocene data compilation, $\mathrm{Mg} / \mathrm{Ca}$-derived SST records either revealed smoother Holocene temperature changes of an opposite sign as compared to alkenone-derived SSTs, or no discernable SST changes (Figs. 1 and 2). This feature illustrates discrepancies between the two paleothermometry methods when considering the Holocene and Eemian periods, and further raises the question for the significance of these SST proxies to faithfully record the mean oceanic temperature background. In the following discussion we outline the strengths and weaknesses of the hypothesized role of the interplay between the Holocene seasonal cycle evolution and the planktonic organisms' ecology in shaping the above-mentioned SST features.

\subsubsection{Latitudinal-dependent alkenone SST evolution}

Almost all low-latitude and high-latitude records of alkenonederived Holocene temperatures seem to record warming and cooling trends, respectively, regardless of regional hydrologic processes. It suggests that changes in ocean dynamics have only played a minor role in shaping these SST records since the abovementioned feature is global, regardless of the contrasted regional hydrologic features covered by the dataset at a given latitude. According to the evolution of winter and summer insolation over the last $10 \mathrm{ka}$ as depicted in Fig. 3, our hypothesis is that alkenone SST captured the low-frequency precessional half-cycle signal which implies that the high- vs. low-latitude blooming season of alkenone-producing coccolithophorids are restricted to boreal summer vs. boreal winter seasons. The boreal summer and winter seasons were accordingly marked by a decreased and increased seasonal irradiation, respectively, providing a firstorder explanation for high- vs. low-latitude SST changes during the Holocene.

The observed feature is particularly marked in the Atlantic Ocean where abundant records are available. Results from the North Atlantic indicate that the cooling trend derived from alkenones is likely due to a summer insolation decline that experienced some tens of $\mathrm{Wm}^{-2}$ during the course of the Holocene (Fig. 3d). The low-latitude warming recorded in the WEA and presumably also in the eastern equatorial Atlantic (Weldeab et al., 2007b) suggest that the alkenones records have imprinted the boreal winter season in the tropical Atlantic, a result that can likely be extended to the entire low-latitude latitudinal band (Figs. 1 and 3). A latitudinal feature is clearly demonstrated by a sediment trap latitudinal transect from the North Atlantic, that reports coccolithophorid flux maxima occurring during short time windows when SSTs are higher (lower) than the annual-mean SST at high (low) latitudes (see Fig. 2 in Bijma et al., 2001). The interhemispheric asymmetry in insolation distribution during the Holocene may also account for the SST decrease as recorded in the Southern Ocean sector (Laskar, 1990; see also Fig. 1 in Lorenz et al., 2006), if we assume that alkenones are mainly produced in this area during late spring (Sikes et al., 1997; Ternois et al., 1998; Prahl et al., 2010).

High-latitude alkenone production may be restricted to the late spring or summer seasons as a result of light limitation. Some support for this statement can be found in a recent core-top compilation which reported that alkenone SST signal production was globally shifted toward these seasons at high latitudes (see Prahl et al., 2010). Satellite data clearly depict a warm season for the blooming of coccolithophorids in the North Atlantic and in the Southern Ocean (Iglesias-Rodriguez et al., 2002). Since light availability at high-latitude is crucial for photosynthetic organisms such as coccolithophorids, it is likely that high-latitude alkenone records would be strongly weighted towards the spring to summer seasons, one interpretation that may apply to alkenone records going even further back in time, well beyond the Holocene time period.

Why the global and persistent warming trend is recorded in almost all of the low-latitude alkenone records as such a strong Holocene SST feature (Figs. 1 and $3 \mathrm{a}-\mathrm{c}$ ) is more puzzling, and can only be explained if alkenone-derived SST records are assumed to reflect the boreal winter season since it coincides with an insolation increase in the tropics. Therefore another factor may have had an impact at low latitudes, e.g., nutrient availability instead of light, since light is not a limiting factor for primary productivity at low latitudes. Possible is that in the permanently stratified tropical ocean where light is no limited low-nutrient surface waters are influenced seasonally by upwelling that acts synchronously to increase the surface water nutrient content - favouring primary productivity - and to decrease SST, potentially making coccolithophorids susceptible to blooms when SSTs are below the meanannual average. A feature that is in agreement with recent satellite observations for an inverse relationship at low latitudes between net primary productivity and temperature, the link between these processes being the upper ocean stratification (Behrenfeld et al., 2006).

However, changes in phytoplankton assemblages due to coccolithophorids vs. diatoms competing for nutrients also need to be considered, so that tropical alkenone warming trends have to be analyzed with models involving biogeochemistry to fully encompass the suite of climatological and biological processes ultimately driving the alkenone-based SST signal. The latter process may at least partly explain why alkenone-derived coretop SST in the Peruvian upwelling are warmer than mean-annual SSTs by up to $3^{\circ} \mathrm{C}$ (Prahl et al., 2010), if the coccolithophorid living period occurs during boreal winter (or austral summer), next to the upwelling season that rather favours diatom productivity in this region.

\subsubsection{The treatment of $\mathrm{Mg} / \mathrm{Ca}$ SST records inconsistencies}

As $\mathrm{Mg} / \mathrm{Ca}$-derived SST trends are often found in lower amplitudes than the uncertainty assigned to this method and derived from calibration equations, it is difficult to assess whether the cooling or warming trends thus far assigned to Holocene $\mathrm{Mg} / \mathrm{Ca}$ derived SST records are statistically robust climate trends or not. We are aware that the magnitude of the trends as depicted in Fig. 2 are only marginally significant in respect to the calibration equations. Only minor cooling or warming in the course of the Holocene supports the assumption that foraminiferal $\mathrm{Mg} / \mathrm{Ca}$ SSTs record temperatures that are more weighted towards mean-annual SSTs despite significant seasonal increases in the abundances recorded in the foraminifera fluxes reported by sediment traps. Additionally, minima or maxima in SSTs may be recorded sometime during the mid-Holocene more often for $\mathrm{Mg} / \mathrm{Ca}$ than for alkenones (Fig. 3), so that the SST trends depicted in Fig. 2 should be interpreted with care. 
In other words, the coccolithophorids that bloom in a very narrow temporal range (Bijma et al., 2001; Iglesias-Rodriguez et al., 2002) are highly susceptible to reflect winter or summer SSTs driven by long-term seasonal insolation changes during the Holocene. On the other hand, foraminifera also bear seasonal fluctuations but often remain abundant over the entire year (see Thunell et al., 1983; Schiebel and Hemleben, 2000; Tedesco and Thunell, 2003; Mohtadi et al., 2009 among others). The difference in the fluxes of planktonic organism dynamics is essential since it may provide an explanation for the contrasted ability of these proxies to generate different magnitudes in long-term SST changes. This difference is a valid reason why $\mathrm{Mg} / \mathrm{Ca}$ SSTs fail to produce a significant magnitude in the computed SST trends if it represents more "mean-annual" SSTs as compared to alkenone-derived SSTs.

Also possible is that some features seen in $\mathrm{Mg} / \mathrm{Ca}$-derived SST records are linked to complex combinations of long-term changes in the ecological behaviour of planktonic foraminifera. One example was provided in Oppo et al. (2009) who reported some evidences for changes in the seasonality of $G$. ruber fluxes through time, with long-term (centennial-scale) oscillations between mean-annual temperatures and the July/August/September mean temperatures. This result is broadly consistent with the idea of long-term foraminifera sampling of boreal summer as we have suggested for this region. Furthermore, it provides an alternative mechanism for explaining why $\mathrm{Mg} / \mathrm{Ca}$ trends are of a lower magnitude than the alkenone trends if low resolution $\mathrm{Mg} / \mathrm{Ca}$ SST records average the summer and annual-mean SSTs.

We, however, note that (1) significant Holocene $\mathrm{Mg} / \mathrm{Ca}$-derived SST trends opposite in sign to those of alkenone-derived SST changes can still be found in many places (Fig. 3), and (2) stronger July insolation changes can potentially lead to significant $\mathrm{Mg} / \mathrm{Ca}-$ derived SST trends during the Eemian in the tropical Pacific (Fig. 4). Taken at face value, the observations suggest that, in some places of the ocean, proxy-related divergent SST trends exist and may be linked to different proxy sensitivities in relation to seasonal insolation changes. If correctly interpreted, these findings may open new opportunities for exploring long-term changes in seasonal temperature contrasts in the marine environment through applying multiple paleothermometry methods.

\subsubsection{Perspectives to further improve the understanding of SST proxies}

Our study raises the awareness of large-scale inconsistencies in SST proxy signals. We further suggest that, once the ecological behaviour of planktonic organisms generating the geologic SST signal are accounted for, comparisons of SST changes derived from both alkenone and $\mathrm{Mg} / \mathrm{Ca}$ can shed some light on seasonality, one crucial climate parameter that has not been thoroughly considered in paleoceanographic reconstructions so far. Listed below are some important issues that remain unresolved and that can still be addressed in future studies.

One of the most critical issues is the lack of a global picture for planktonic organisms fluxes in sediment trap studies focused on comparing coccolithophorids and foraminifera together. While a large number of sediment trap studies exist, a compilation effort of available information on this issue will help to constrain whether the statements we have made here regarding the importance of planktonic organism ecology for generating one climatic signal from marine sediment cores can be generalized to all oceanic regions.

Another important issue relates to the overall location of the sedimentary records that remain confined to continental margins, such that the mean oceanic state of, e.g., mid-latitude gyres remains poorly sampled. This is due to the very low sedimentation rates that are inherent to oceanic areas distant from coastal zones that drastically limit the possibilities of obtaining SST data with a reasonable resolution for Holocene SST reconstructions. Few available records surrounding Hawaii (based on alkenones (Lee et al., 2001)) and the Azorean archipelagos (based on $\mathrm{Mg} / \mathrm{Ca}$ (Repschläger et al., 2009)), however, seem to confirm the hypothesis we have suggested for low-latitude SST responses to seasonal insolation changes.

Finally, only a very few pieces of evidence from multiproxy SST reconstructions have been derived from the same sedimentary sequences, confirming our ecological hypothesis (Weldeab et al., 2007a, b for the eastern equatorial Atlantic; Nürnberg et al., 2008 and Nürnberg and Blanz, Pers. Comm. for the western equatorial Atlantic; Koutavas and Sachs, 2008 and Koutavas et al., 2006 for the eastern equatorial Pacific; Sachs, 2007 and Keigwin et al., 2005 for the North Altlantic). The clustering of sedimentary records sometimes involving sedimentary sequences very close to each other such as those around the Galapagos Islands or in the Cariaco Basin - and those reporting SST features in the oceanic regions we have investigated in Fig. 3 suggest that regional features are robust for both alkenones- and, to a lesser extent, for $\mathrm{Mg} / \mathrm{Ca}$-based SST reconstructions. However, the fact that $\mathrm{Mg} / \mathrm{Ca}$ SST may represent local features would imply that systematic multiproxy studies from the same sedimentary sequence still need to be performed more extensively.

\section{Conclusions}

The compilation of SST data available for the Holocene and derived from two different proxies (alkenone unsaturation vs. $\mathrm{Mg}$ / Ca ratios) suggests that the processes that drive the sedimentary record of the interglacial SST evolution may be unexpectedly complex and our understanding is only fragmentary. Although the alkenone-derived SST trends previously identified are robust, they are not reproduced by the $\mathrm{Mg} / \mathrm{Ca}$-derived SST records. The observation suggests that the regional paleoceanographic dynamics interacting with phytoplankton and zooplankton ecological behaviour affect SST records with a strong seasonal imprint in the geological record. If this ecological hypothesis is true, it implies that one should interpret with care any comparison made from SSTs derived from mixed proxies, such as for mapping efforts focused on reconstructing SST fields at targeted time slices (MARGO, 2009). Since multiproxy SST reconstructions indicate that paleotemperature proxies contain complex information, as previously suggested by studies that deal with the calibration of paleothermometry methods in the modern ocean, future research should fully consider these issues in modelling experiments in order to enlighten our understanding of SST evolution during interglacial periods.

We are fully aware of numerous weaknesses in our interpretation regarding the observed proxy-dependent Holocene SST trends. For example, field studies of temporal changes in coccolithophorid productivity and/or in foraminifera fluxes are not always reporting a behaviour of planktonic organisms as we implicitly suggest in our conceptual model. However, in order to reconcile the evidences for Holocene alkenone-derived SST trends with those from the $\mathrm{Mg} / \mathrm{Ca}$ method that do not reproduce these trends, our straightforward assumption that the explanation relates to the seasonality in hydrographic conditions and to the difference in the response of plankton growth during different seasons remains powerful since it can explain many first-order trends that were observed in our datasets. Although the Eemian-Holocene comparison may suffer from the precision and accuracy of the Eemian dating strategy for many reasons, efforts toward re-dating marine cores independently of the SPECMAP record should be one potential way to refute or confirm the statements we have made here regarding the mechanisms shaping interglacial SST trends. Recent efforts to transfer 
radiometric dates from corals and speleothems to marine records could resolve this difficulty for particular sites (Waelbroeck et al., 2008; Drysdale et al., 2009).

\section{Acknowledgements}

We thank Julian Sachs, David Lea and Birgit Schneider for insightful discussions. Thomas Blanz and Dirk Nürnberg are thanked for sharing knowledge on unpublished alkenone-derived SST data from MD02-2575 marine sediment core. We believe that the thorough and constructive comments made by two anonymous reviewers significantly improved the quality of this study. This work has been financed by the German Research Foundation (DFG) in the framework of the German Research Priority Program SPP1266 (INTERDYNAMIK).

\section{References}

Anand, P., Elderfield, H., Conte, M.H., 2003. Calibration of $\mathrm{Mg} / \mathrm{Ca}$ thermometry in planktonic foraminifera from a sediment trap time series. Paleoceanography 18 (2), 1050. doi:10.1029/2002PA000846.

Arz, H.W., Lamy, F., Pätzold, J., Müller, V., Prins, M., 2003. Mediterranean moisture source for an Early-Holocene humid period in the Northern Red Sea. Science 300, 118-121.

Bard, E., Rostek, F., Sonzogni, C., 1997. Interhemispheric synchrony of the last deglaciation inferred from alkenone palaeothermometry. Nature 385, 707-710.

Bard, E., Rostek, F., Turon, J.-L., Gendreau, S., 2000. Hydrological impact of Heinrich events in the subtropical northeast Atlantic. Science 289, 1321-1324.

Bard, E., 2001. Paleoceanographic implications of the difference in deep-sea sediment mixing between large and fine particles. Paleoceanography 16 (3), 235-239.

Barron, J.A., Heusser, L., Herbert, T., Lyle, M., 2003. High resolution climatic evolution of coastal Northern California during the past 16,000 Years. Paleoceanography 18, PA1020. doi:10.1029/2002PA000768.

Barrows, T.T., Lehman, S.J., Fifield, L.K., De Deckker, P., 2008. Absence of cooling in New Zealand and the adjacent ocean during the Younger Dryas chronozone. Science 318, 86-89.

Behrenfeld, M.J., O’Malley, R., Siegel, D., McClain, C., Sarmiento, J., Feldman, G., Milligan, A., Falkowski, P., Letelier, R., Boss, E., 2006. Climate-driven trends in contemporary ocean productivity. Nature 444, 752-755.

Bendle, J.A., Rosell-Melé, A., 2007. High resolution alkenone sea surface temperature variability on the North Icelandic Shelf: implications for Nordic Seas paleoclimatic development during the Holocene. The Holocene 17 (1), 19-24.

Benway, H.M., Mix, A.C., Haley, B.A., Klinkhammer, G.P., 2006. Eastern Pacific warm pool paleosalinity and climate variability: 0-30 kyr. Paleoceanography 21, PA3008. doi:10.1029/2005PA001208.

Bijma, J., Altabet, M., Conte, M., Kinkel, H., Versteegh, G.J.M., Volkman, J.K., Wakeham, S.G., Weaver, P.P., 2001. Primary signal: ecological and environmental factors-report from working group 2. Geochemistry, Geophysics, Geosystems 2. doi:10.1029/2000GC000051.

Braconnot, P., Marzin, C., Gregoire, L., Mosquet, E., Marti, O., 2008. Monsoon response to changes in Earth's orbital parameters: comparisons between simulations of the Eemian and of the Holocene. Climate of the Past 4, 281-294.

Cacho, I., Grimalt, J., Pelejero, C., Canals, M., Sierro, F., Flores, J., Shackleton, N., 1999. Dansgaard-Oeschger and Heinrich Event imprints in Alboran Sea paleotemperatures. Paleoceanography 14 (6), 698-705.

Cacho, I., Grimalt, J.O., Canals, M., Sbaffi, L., Schackleton, N.J., Schonfeld, J., Zahn, R., 2001. Variability of the Western Mediterranean sea surface temperatures during the last 25000 years and its connection with the northern hemisphere climatic changes. Paleoceanography 16, 40-52.

Calvo, E., Grimalt, J., Ganssen, E., 2002. High resolution $U_{37}^{K}$ sea surface temperature reconstruction in the Norwegian Sea during the Holocene. Quaternary Science Reviews 21, 1385-1394.

Calvo, E., Pelejero, C., De Deckker, P., Logan, G.A., 2007. Antarctic deglacial pattern in a $30 \mathrm{kyr}$ record of sea surface temperature offshore South Australia. Geophysical Research Letters 34, L13707. doi:10.1029/2007GL029937.

Came, R.E., Oppo, D.W., McManus, J.F., 2007. Amplitude and timing of temperature and salinity variability in the subpolar North Atlantic over the last 10,000 years. Geology 35, 315-318.

Chen, Y.-L.L., Chen, H.-Y., 2006. Seasonal dynamics of primary and new production in the northern South China Sea: the significance of river discharge and nutrient advection. Deep Sea Research Part I 53, 971-986.

Conkright, M.E., Boyer, T.P., 2002. World Ocean Atlas 2001: Objective Analyses, Data Statistics, and Figures, CD-ROM Documentation. National Oceanographic Data Center, Silver Spring, MD, 17 pp.

Conte, M.H., Sicre, M.A., Rühlemann, C., Weber, J.C., Schulte, S., Schulz-Bull, D., Blanz, T., 2006. Global temperature calibration of the alkenone unsaturation index (UK' 37 ) in surface waters and comparison with surface sediments. Geochemistry, Geophysics, Geosystems 7, Q02005. doi:10.1029/2005GC001054.
Dansgaard, W., Johnsen, S.J., Clausen, H.B., Dahl-Jensen, D., Gundestrup, N.S., Hammer, C.U., Hvidberg, C.S., Steffensen, J.P., Sveinjörnsdottir, A.E., Jouzel, J., Bond, G., 1993. Evidence for general instability of past climate from a 250-kyr ice-core record. Nature 364, 218-220.

Dekens, P.S., Lea, D.W., Pak, D.K., Spero, H.J., 2002. Core top calibration of $\mathrm{Mg} / \mathrm{Ca}$ in tropical foraminifera: refining paleotemperature estimation. Geochemistry, Geophysics, Geosystems 3 (4), 1022. doi:10.1029/2001GC000200.

Drysdale, R.N., Hellstrom, J.C., Zanchetta, G., Fallick, A.E., Sánchez Gõni, M.F., Couchoud, I., McDonald, J., Maas, R., Lohmann, G., Isola, I., 2009. Evidence for obliquity forcing of glacial termination II. Science 325, 1527-1531.

Elderfield, H., Ganssen, G., 2000. Past temperature and $\delta^{18} \mathrm{O}$ of surface ocean waters inferred from foraminifera $\mathrm{Mg} / \mathrm{Ca}$ ratios. Nature 405, 442-445.

Emeis, K.-C., Struck, U., Schulz, H.-M., Rosenberg, R., Bernasconi, S., Erlenkeuser, H. Sakamoto, T., Martinez-Ruiz, F., 2000. Temperature and salinity variations of Mediterranean Sea surface waters over the last 16,000 years from records of planktonic stable oxygen isotopes and alkenone unsaturation ratios. Palaeogeography, Palaeoclimatology, Palaeoecology 158, 259-280.

Emeis, K.-C., Dawson, A., 2003. Holocene paleoclimate records over Europe and the North-Atlantic. The Holocene 13 (3), 305-309.

Emeis, K.-C., Struck, U., Blanz, T., Kohly, A., Voss, M., 2003a. Salinity changes in the Centra Baltic Sea (NW Europe) over the last 10000 years. The Holocene 13 (3), 413-423.

Emeis, K.-C., Schulz, H., Struck, U., Rossignol-Strick, M., Erlenkeuser, H., Howell, M.W., Kroon, D., Mackensen, A., Ishizuka, S., Oba, T., Sakamoto, T. Koizumi, I., 2003b. Eastern Mediterranean surface water temperatures and d180 composition during deposition of sapropels in the late Quaternary. Paleoceanography 18 (1), 1005. doi:10.1029/2000PA000617.

Farmer, E.C., de Menocal, P.B., Marchitto, T.M., 2005. Holocene and deglacial ocean temperature variability in the Benguela upwelling region: implications for lowlatitude atmospheric circulation. Paleoceanography 20, PA2018. doi:10.1029/ 2004PA001049.

Farmer, E.J., Chapman, M.R., Andrews, J.E., 2008. Centennial-scale Holocene North Atlantic surface temperatures from $\mathrm{Mg} / \mathrm{Ca}$ ratios in Globigerina bulloides. Geochemistry, Geophysics, Geosystems 9, Q12029. doi:10.1029/2008GC002199.

Fraile, I., Schulz, M., Mulitza, S., Merkel, U., Prange, M., Paul, A., 2009. Modeling the seasonal distribution of planktonic foraminifera during the Last Glacial Maximum. Paleoceanography 24, PA2216. doi:10.1029/2008PA001686.

Greaves, M., et al., 2008. Interlaboratory comparison study of calibration standards for foraminiferal $\mathrm{Mg} / \mathrm{Ca}$ thermometry. Geochemistry, Geophysics, Geosystems 9, Q08010. doi:10.1029/2008GC001974.

Harada, N., Ahagon, N., Sakamoto, T., Uchida, M., Ikehara, M., Shibata, Y., 2006. Rapid flucatuation of alkenone temperature in the southwestern Okhotsk Sea during the past $120 \mathrm{ky}$. Global and Planetary Change 53, 29-46.

Hastings, D., Kienast, M., Steinke, S., Whitko, A., 2001. A Comparison of three independent paleotemperature estimates from a high resolution record of deglacial SST records in the tropical South China Sea. Eos 82, PP12B-10.

Herbert, T.D., Schuffert, J.D., 2000. History of sea surface temperature variations in Cariaco Basin over a full glacial-interglacial cycle. Proceedings of the Ocean Drilling Program, Scientific Results 165, 239-247.

Herbert, T.D., Schuffert, J.D., Andreasen, D., Heusser, L., Lyle, M., Mix, A., Ravelo, A.C. Stott, L.D., Herguera, J.C., 2001. Collapse of the California current during glacial maxima linked to climate change on land. Science 293, 71-76.

Hillaire-Marcel, C., de Vernal, A., 2008. Comment on mixed-layer deepening during Heinrich events: a multi-planktonic foraminiferal $\delta^{18} \mathrm{O}$ approach Science 320, 1161.

Huang, C.-Y., Wu, S.-F., Zhao, M., Chen, M.-T., Wang, C.-H., Tu, X., Yuan, P.B., 1997. Surface ocean and monsoon climate variability in the south China Sea since last glaciation. Advances in Marine Biology 32, 71-94.

Huybers, P., Curry, W., 2006. Links between annual, Milankovitch and continuum temperature variability. Nature 441, 329-332.

Huybers, P., Wunsch, C., 2003. Rectification and precession signals in the climate system. Geophysical Research Letters 30 (19), 2011. doi:10.1029/2003GL017875.

Iglesias-Rodriguez, M.D., Brown, C.W., Doney, S.C., Kleypas, J., Kolber, D., Kolber, Z. Hayes, P.K., Falkowski, P.G., 2002. Representing key phytoplankton functional groups in ocean carbon cycle models: coccolithophorids. Global Biogeochem. Cycles 16 (4), 1100. doi:10.1029/2001GB001454.

Jaeschke, A., Rühlemann, C., Arz, H., Heil, G., Lohmann, G., 2007. Coupling of millennial-scale changes in sea surface temperature and precipitation of northeastern Brazil with high-latitude climate shifts during the last glacial period. Paleoceanography 22, PA4206. doi:10.1029/2006PA001391.

Kaiser, J., Lamy, F., Hebbeln, D., 2005. A 70-kyr sea surface temperature record off southern Chile (Ocean Drilling Program Site 1233). Paleoceanography 20 PA4009. doi:10.1029/2004PA001146.

Kaiser, J., Schefub, E., Lamy, F., Mohtadi, M., Hebbeln, D., 2008. Glacial to Holocene changes in sea surface temperature and coastal vegetation in north centra Chile: high versus low latitude forcing. Quaternary Science Reviews 27, 2064-2075.

Keigwin, L.D., Sachs, J.P., Rosenthal, Y., Boyle, E.A., 2005. The 8200 year B.P. event in the slope water system, western subpolar North Atlantic. Paleoceanography 20 , PA2003. doi:10.1029/2004PA001074.

Kienast, M., Steinke, S., Stattegger, K., Calvert, S.E., 2001. Synchronous tropical South China Sea SST change and Greenland warming during deglaciation. Science 291, 2132-2134.

Kienast, M., Kienast, S.S., Calvert, S.E., Eglinton, T.I., Mollenhauer, G., François, R Mix, A., 2006. Eastern Pacific cooling and Atlantic overturning circulation during the last deglaciation. Nature $443,846-849$. 
Kienast, S.S., McKay, J.L., 2001. Sea surface temperature in the subarctic Northeast Pacific reflect millennial-scale climate oscillations during the last 16 kyrs. Geophysical Research Letters 28, 1563-1566.

Kim, J.-H., Schneider, R.R., Müller, P.J., Wefer, G., 2002a. Interhemispheric comparison of deglacial sea-surface temperature patterns in Atlantic eastern boundary currents. Earth and Planetary Science Letters 194, 383-393.

Kim, J.-H., Schneider, R.R., Hebbeln, D., Müller, P.J., Wefer, G., 2002b. Last deglacial seasurface temperature evolution in the Southeast Pacific compared to climate changes on the South American continent. Quaternary Science Reviews 21, 2085-2097.

Kim, J.-H., Schneider, R.R., Mulitza, S., Müller, P.J., 2003. Reconstruction of SE trade wind intensity based on sea-surface temperature gradients in the SE Atlantic over the last 25 kyr. Geophysical Research Letters 30, 2144. doi:10.1029/ 2003GL017557.

Kim, J.-H., Rimbu, N., Lorenz, S.J., Lohmann, G., Nam, S.-I., Schouten, S., Rühlemann, C., Schneider, R.R., 2004. North Pacific and North Atlantic seasurface temperature variability during the Holocene. Quaternary Science Reviews 23 (20-22), 2141-2154.

Kim, J.-H., Schneider, R.R., 2004. GHOST global database for alkenone-derived Holocene sea-surface temperature records. Available from: <http://www. pangaea.de/Projects/GHOST $>$.

Kim, J.-H., Meggers, H., Rimbu, N., Lohmann, G., Freudenthal, T., Müller, P.J., Schneider, R.R., 2007. Impact of the North Atlantic gyre circulation on Holocene climate off Northwest Africa. Geology 35, 387-390.

Kisakurek, B., Eisenhauer, A., Böhm, F., Garbe-Schönberg, D., Erez, J., 2008. Controls on shell $\mathrm{Mg} / \mathrm{Ca}$ and $\mathrm{Sr} / \mathrm{Ca}$ in cultured planktonic foramininferan, Globigerinoides ruber (white). Earth and Planetary Science Letters 273, 260-269.

Koutavas, A., Lynch-Stieglitz, J., Marchitto, T.M., Sachs, J.P., 2002. El Niño-like pattern in ice age tropical pacific sea surface temperature. Science 297, 226-230.

Koutavas, A., de Menocal, P.B., Olive, G.C., Lynch-Stieglitz, J., 2006. Mid-Holocene E Niño-Southern Oscillation (ENSO) attenuation revealed by individual foraminifera in eastern tropical Pacific sediments. Geology 34, 993-996.

Koutavas, A., Sachs, J.P., 2008. Northern timing of deglaciation in the eastern equatorial Pacific from alkenone paleothermometry. Paleoceanography 23 , PA4205. doi:10.1029/2008PA001593.

Kudrass, H.R., Hofmann, A., Doose, H., Emeis, K., Erlenkeuser, H., 2001. Modulation and amplification of climatic changes in the Northern Hemisphere by the Indian summer monsoon during the past 80 k.y. Geology 29, 63-66.

Laepple, T., Lohmann, G., 2009. The seasonal cycle as template for climate variability on astronomical time scales. Paleoceanography 24, PA4201. doi:10.1029| 2008PA001674.

Laskar, J., 1990. The chaotic motion of the solar system: A numerical estimate of the size of the chaotic zones. Icarus 88, 266-291.

von Langen, P.J., Pak, D.K., Spero, H.J., Lea, D.W., 2005. Effects of temperature on Mg/ $\mathrm{Ca}$ in neogloboquadrinid shells determined by live culturing. Geochemistry, Geophysics, Geosystems 6, Q10P03. doi:10.1029/2005GC000989.

Lea, D.W., Pak, D.K., Spero, H.J., 2000. Climate impact of late quaternary equatoria Pacific sea surface temperature variations. Science 289, 1719-1724.

Lea, D.W., Pak, D.K., Peterson, L.C., Hughen, K.A., 2003. Synchroneity of tropical and high-latitude Atlantic temperatures over the last glacial termination. Science 301, 1361-1364.

Lea, D.W., Pak, D.K., Belanger, C.L., Spero, H.J., Hall, M.A., Shackleton, N.J., 2006. Paleoclimate history of Galápagos surface waters over the last 135,000 years. Quaternary Science Reviews 25, 1152-1167.

Leduc, G., Vidal, L., Tachikawa, K., Rostek, F., Sonzogni, C., Beaufort, L., Bard, E., 2007. Moisture transport across Central America as a positive feedback on abrup climatic changes. Nature 445, 908-911.

Lee, K., Slowey, N., Herbert, T., 2001. Glacial sea surface temperatures in the Subtropical North Pacific: a comparison of $\mathrm{U}_{37}^{\mathrm{k}^{\prime}}, \delta^{18} \mathrm{O}$, and foraminiferal assemblage temperature estimates. Paleoceanography 16 (3), 268-279.

Levi, C., Labeyrie, L., Bassinot, F., Guichard, F., Cortijo, E., Waelbroeck, C., Caillon, N., Duprat, J., de Garidel-Thoron, T., Elderfield, H., 2007. Low-latitude hydrological cycle and rapid climate changes during the last deglaciation. Geochemistry, Geophysics, Geosystems 8, Q05N12. doi:10.1029/2006GC001514.

Lorenz, S., Lohmann, G., 2004. Acceleration technique for Milankovitch type forcing in a coupled atmosphere-ocean circulation model: method and application for the Holocene. Climate Dynamics 23 (7-8), 727-743.

Lorenz, S.J., Kim, J.-H., Rimbu, N., Schneider, R.R., Lohmann, G., 2006. Orbitally driven insolation forcing on Holocene climate trends: evidence from alkenone data and climate modeling. Paleoceanography 21, PA1002. doi:10.1029/ 2005PA001152.

Lückge, A., Mohtadi, M., Rühlemann, C., Scheeder, G., Vink, A., Reinhardt, L., Wiedicke, M., 2009. Monsoon versus ocean circulation controls on paleoenvironmental conditions off southern Sumatra during the past 300,000 years. Paleoceanography 24, PA1208. doi:10.1029/2008PA001627.

Marchal, O., et al., 2002. Apparent long-term cooling of the sea surface in the northeast Atlantic and Mediterranean during the Holocene. Quaternary Science Reviews 21, 455-483.

Martrat, B., Grimalt, J.O., Lopez-Martinez, C., Cacho, I., Sierro, F.J., Flores, J.A., Zahn, R., Canals, M., Curtis, J.H., Hodell, D.A., 2004. Abrupt Temperature Changes in the Western Mediterranean over the Past 250,000 Years. Science 306, 1762-1765.

MARGO project members, 2009. Constraints on the magnitude and patterns of ocean cooling at the Last Glacial Maximum. Nature Geoscience 2, 127-132.

Martrat, B., Grimalt, J.O., Shackleton, N.J., de Abreu, L., Hutterli, M.A., Stocker, T.F., 2007. Four climate cycles of recurring deep and surface water destabilizations on the Iberian Margin. Science 27, 502-507.
Mashiotta, T.A., Lea, D.W., Spero, H.J., 1999. Glacial-interglacial changes in Subantarctic sea surface temperature and d180-water using foraminiferal Mg. Earth and Planetary Science Letters 170 (4), 417-432.

Mayewski, P.A., et al., 2004. Holocene climate variability. Quaternary Research 2, 243-255.

Mekik, F., François, R., Soon, M., 2007. A novel approach to dissolution correction of $\mathrm{Mg} /$ Ca-based paleothermometry in the tropical Pacific. Paleoceanography 22, PA3217. doi:10 1029/2007PA001504.

Mix, A.C., 2006. Running hot and cold in the eastern equatorial Pacific. Quaternary Science Reviews 25, 1147-1149.

Mohtadi, M., Steinke, S., Groeneveld, J., Fink, H.G., Rixen, T., Hebbeln, D., Donner, B., Herunadi, B., 2009. Low-latitude control on seasonal and inter-annual changes in planktonic foraminiferal flux and shell geochemistry off south Java: a sediment trap study. Paleoceanography 24, PA1201. doi:10.1029/2008PA001636.

Müller, P.J., Kirst, G., Ruhland, G., von Storch, I., Rosell-Melé, A., 1998. Calibration of the alkenone paleotemperature index $U_{37}^{K^{\prime}}$ based on core-tops from the eastern South Atlantic and the global ocean $\left(60^{\circ} \mathrm{N}-60^{\circ} \mathrm{S}\right)$. Geochimica et Cosmochimica Acta $62,1757-1772$.

Nürnberg, D., Bijma, J., Hemleben, C., 1996. Assessing the reliability of magnesium in foraminiferal calcite as a proxy for water mass temperature. Geochimica et Cosmochimica Acta 60, 803-814.

Nürnberg, D., Ziegler, M., Karas, C., Tiedemann, R., Schmidt, M.W., 2008. Interacting Loop Current variability and Mississippi River discharge over the past $400 \mathrm{kyr}$. Earth and Planetary Science Letters 272, 278-289.

Ohkouchi, N., Eglinton, T.I., Keigwin, L.D., Hayes, J.M., 2002. Spatial and temporal offsets between proxy records in a sediment drift. Science 298, 1224-1227.

Oppo, D.W., Sun, Y., 2007. Amplitude and timing of sea surface temperature change in the northern South China Sea: dynamic link to the East Asian Monsoon. Geology 33, 785-788.

Oppo, D.W., Rosenthal, Y., Linsley, B., 2009. 2,000-year-long temperature and hydrology reconstructions from the Indo-Pacific warm pool. Nature 460 , $1113-1116$.

Ostertag-Henning, C., Stax, R., 2000. Data report: carbonate records from sites 1012, 1013, 1017, and 1019 and alkenone-based sea-surface temperatures from site 1017. Proceedings of the Ocean Drilling Program. Scientific Results Ocean Drilling Program 167, 297-302.

Pahnke, K., Zahn, R., Elderfield, H., Schulz, M., 2003. 340,000 Year centennial-scale marine record of southern hemisphere climatic oscillation. Science 301, 948-952.

Pahnke, K., Sachs, J.P., 2006. Sea surface temperatures of southern middle-latitudes 0-160 ky BP. Paleoceanography 21, PA2003. doi:10.1029/2005PA001191.

Pahnke, K., Sachs, J.P., Keigwin, L., Timmermann, A., Xie, S.-P., 2007. Eastern tropical Pacific hydrologic changes during the past 27,000 years from $\mathrm{D} / \mathrm{H}$ ratios in alkenones. Paleoceanography 22, PA4214. doi:10.1029/2007PA001468.

Pailler, D., Bard, E., 2002. High frequency paleoceanographic changes during the past 140,000 years recorded by the organic matter in sediments off the Iberian Margin. Palaeogeography, Palaeoclimatology and Palaeoecology 181, 431-452.

Partin, J.W., Cobb, K.M., Adkins, J.F., Clark, B., Fernandez, D.P., 2007. Millennial-scale trends in west Pacific warm pool hydrology since the Last Glacial Maximum. Nature 449, 452-455.

Pelejero, C., Grimalt, J.O., 1997. The correlation between the Uk37 index and sea surface temperatures in the warm boundary: the South China Sea. Geochim. et Cosmochim. Acta 61, 4789-4797.

Pelejero, C., Grimalt, J.O., Heilig, S., Kienast, M., Wang, L., 1999. High-resolution UK37 temperature reconstructions in the South China Sea over the past $220 \mathrm{kyr}$. Paleoceanography 14, 224-231.

Pena, L.D., Cacho, I., Ferretti, P., Hall, M.A., 2008. El Niño-Southern Oscillation-like variability during glacial terminations and interlatitudinal teleconnections. Paleoceanography 23, PA3101. doi:10.1029/2008PA001620.

Pennington, J.T., Mahoney, K.L., Kuwahara, V.S., Kolber, D.D., Calienes, R., Chavez, F.P., 2006. Primary production in the eastern tropical Pacific. Progress. Oceanography 69, 285-317.

Prahl, F.G., Wakeham, S.G., 1987. Calibration of unsaturation patterns in long-chain ketone compositions for paleotemperature assessment. Nature 330, 367-369.

Prahl, F.G. Muehlhausen, L.A., Zahnle, D.L. 1988. Further evaluation of long-chain alkenones as indicators of paleoceanographic conditions. Geochimica et Cosmochimica Acta 52, 2303-2310.

Prahl, F.G., Mix, A.C., Sparrow, M.A., 2006. Alkenone paleothermometry: biological lessons from marine sediment records off Western South America. Geochimica et Cosmochimica Acta 70, 101-117.

Prahl, F.G., Rontani, J.-F., Zabeti, N., Walinsky, S.E., Sparrow, M.A., 2010. Summerbiased sea-surface temperature record for alkenones in SE Alaskan surface sediments. Geochimica et Cosmochimica Acta 74, 131-143.

Repschläger, J., Weinelt, M., Andersen, N., Garbe-Schönberg, D., 2009. Monitoring multi-decadal to multi-centennial variability of AMOC strength in the subtropical Northeast Atlantic over Holocene and Eemian. Geophysical Research Abstracts 11 EGU2009-11306.

Regenberg, M., Nürnberg, D., Steph, S., Groeneveld, J., Garbe-Schönberg, D., Tiedemann, R., Dullo, W.-C., 2006. Assessing the effect of dissolution on planktonic foraminiferal $\mathrm{Mg} / \mathrm{Ca}$ ratios: evidence from Caribbean core tops. Geochemistry, Geophysics, Geosystems 7, Q07P15. doi:10.1029/2005GC001019.

Regenberg, M., Steph, S., Nürnberg, D., Tiedemann, R., Garbe-Schönberg, D., 2009. Calibrating $\mathrm{Mg} / \mathrm{Ca}$ ratios of multiple planktonic foraminiferal species with $\delta^{18} \mathrm{O}$ calcification temperatures: paleothermometry for the upper water column. Earth and Planetary Science Letters 278, 324-336. 
Renssen, H., Seppä, H., Heiri, O., Roche, D.M., Goosse, H., Fichefet, T., 2009. The spatial and temporal complexity of the Holocene thermal maximum. Nature Geosciences 2, 411-414.

Rimbu, N., Lohmann, G., Kim, J.-H., Arz, H., Schneider, R.R., 2003. Arctic/North Atlantic oscillation signature in Holocene sea surface temperature trends as obtained from alkenone data. Geophysical Research Letters 30 (6), 1280. doi:10.1029/2002GL016570.

Rimbu, N., Lohmann, G., Lorenz, S.J., Kim, J.-H., Schneider, R.R., 2004. Holocene climate variability as derived from alkenone sea surface temperature reconstructions and coupled ocean-atmosphere model experiments. Climate Dynamics 23 (2), 215-227.

Rodrigues, T., Grimalt, J.O., Abrantes, F.G., Flores, J.A., Lebreiro, S.M., 2009. Holocene interdependences of changes in sea surface temperature, productivity, and fluvial inputs in the Iberian continental shelf (Tagus mud patch). Geochemistry, Geophysics, Geosystems 10, Q07U06. doi:10.1029/2008GC002367.

Romero, O.E., Kim, J.-H., Donner, B., 2008. Submillennial-to-millennial variability of diatom production off Mauritania, NW Africa, during the last glacial cycle. Paleoceanography 23, PA3218. doi:10.1029/2008PA001601.

Rosell-Melé, A., Eglinton, G., Pflaumann, U., Sarnthein, M., 1995. Atlantic core-top calibration of the UK37 index as a sea-surface palaeotemperature indicator Geochimica et Cosmochimica Acta 59, 3099-3107.

Rosell-Melé, A., et al., 2001. Precision of the current methods to measure the alkenone proxy UK'37 and absolute alkenone abundance in sediments: results of an interlaboratory comparison study. Geochemistry, Geophysics, Geosystems 2 (7). doi:10.1029/2000GC000141.

Rosenthal, Y., Lohmann, G.P., 2002. Accurate estimation of sea surface temperatures using dissolution-corrected calibration for $\mathrm{Mg} / \mathrm{Ca}$ paleothermometry. Paleoceanography 17. doi:10.1029/2001PA000749.

Rosenthal, Y., Oppo, D.W., Linsley, B.K., 2003. The amplitude and phasing of climate change during the last deglaciation in the Sulu Sea, western equatorial Pacific. Geophysical Research Letters 30 (8), 1428. doi:10.1029/2002GL016612.

Rosenthal, Y., et al., 2004. Interlaboratory comparison study of $\mathrm{Mg} / \mathrm{Ca}$ and $\mathrm{Sr} / \mathrm{Ca}$ measurements in planktonic foraminifera for paleoceanographic research. Geochemistry, Geophysics, Geosystems 5, O04D09. doi:10.1029/2003GC000650.

Rühlemann, C., Mulitza, S., Müller, P.J., Wefer, G., Zahn, R., 1999. Warming of the tropical Atlantic Ocean and slowdown of thermohaline circulation during the last deglaciation. Nature 402, 511-514.

Sachs, J.P., 2007. Cooling of Northwest Atlantic slope waters during the Holocene. Geophysical Research Letters 34, L03609. doi:10.1029/2006GL028495.

Sawada, K., Handa, N., 1998. Variability of the path of the Kuroshio ocean current over the past 25,000 years. Nature 392, 592-595.

Schefuß, E., Schouten, S., Schneider, R.R., 2005. Climatic controls on central African hydrology during the last 20,000 years. Nature 437, 1003-1006.

Schiebel, R., Hemleben, C., 2000. Interannual variability of planktonic foraminifera populations and test fluxes in the eastern North Atlantic Ocean (JGOFS). Deep Sea Research Part II 47, 1809-1852.

Schlitzer, R., 2004. Ocean Data View software. Available from: <http://odv.awi.de $>$.

Schmidt, M.W., Spero, H.J., Lea, D.W., 2004. Links between salinity variation in the Caribbean and North Atlantic thermohaline circulation. Nature 428, 160-163.

Schulz, H., Emeis, K.-C., Erlenkeuser, H., von Rad, U., Rolf, C., 2002. The Toba volcanic event and interstadial/stadial climates at the marine isotopic stage 5 to 4 transition in the Northern Indian Ocean. Quarterly Research 57, 22-31.

Seki, O., Ikehara, M., Kawamura, K., Nakatsuka, T., Ohnishi, K., Wakatsuchi, M., Narita, H., Sakamoto, T., 2004. Reconstruction of paleoproductivity in the Sea of Okhotsk over the last 30 kyr. Paleoceanography 19, PA1016. doi:10.1029/ 2002PA000808.

Sikes, E., Volkman, J.K., Robertson, L.G., Pichon, J.-J., 1997. Alkenones and alkenes in surface waters and sediments of the Southern Ocean: implications for paleotemperature estimation in polar regions. Geochimica et Cosmochimica Acta 61, 1495-1505.

Sikes, E.L., Howard, W.R., Neil, H.L., Volkman, J.K., 2002. Glacial-interglacial sea surface temperature changes across the subtropical front east of New Zealand based on alkenone unsaturation ratios and foraminiferal assemblages. Paleoceanography 17 (2), 1012. doi:10.1029/2000PA000640.

Skinner, L.C., Elderfield, H., 2005. Constraining ecological and biological bias in planktonic foraminiferal $\mathrm{Mg} / \mathrm{Ca}$ and $\delta^{18} \mathrm{Occ}$ : a multispecies approach to proxy calibration testing. Paleoceanography 20, PA1015. doi:10.1029/2004PA001058.
Sonzogni, C., Bard, E., Rostek, F., Lafont, R., Rosell-Melé, A., Eglinton, G., 1997. Coretop calibration of the alkenone index vs sea surface temperture in the Indian Ocean. Deep Sea Research Part II 44, 1445-1460.

Sonzogni, C., Bard, E., Rostek, F., 1998. Tropical sea surface temperatures during the last glacial period: a view based on alkenones in Indian Ocean sediments. Quaternary Science Reviews 17, 1185-1201.

Sperling, M., Schmiedl, G., Hemleben, C., Emeis, K.-C., Erlenkeuser, H., Grootes, P., 2003. Black Sea impact on the formation of eastern Mediterranean sapropel S1: evidence from the Marmara Sea. Palaeogeography, Palaeoclimatology, Palaeoecology 190, 9-21.

Steinke, S., Kienast, M., Groeneveld, J., Lin, L.-C., Chen, M.-T., Rendle-Bühring, R. 2008. Proxy dependence of the temporal pattern of deglacial warming in the tropical South China Sea: toward resolving seasonality. Quaternary Science Reviews 27, 688-700.

Stott, L.D., Cannariato, K., Thunell, R., Haug, G., Koutavas, A., Lund, S., 2004. Decline of western tropical pacific surface ocean temperatures and salinities in the Holocene. Nature 431, 56-59.

Sun, Y., Oppo, D.W., Xiang, R., Liu, W., Gao, S., 2005. The last deglaciation in the Okinawa Trough: subtropical northwest Pacific link to northern and tropical climate. Paleoceangraphy 20, PA4005. doi:10.1029/2004PA001061.

Tachikawa, K., Sépulcre, S., Toyofuku, T., Bard, E., 2008. Assessing influence of diagenetic carbonate dissolution on planktonic foraminiferal $\mathrm{Mg} / \mathrm{Ca}$ in the southeastern Arabian Sea over the past 450 ka: comparison between Globigerinoides ruber and Globigerinoides sacculifer. Geochemistry, Geophysics, Geosystems 9, Q04037. doi:10.1029/2007GC001904.

Tedesco, K.A., Thunell, R.C., 2003. Seasonnal and interannual variations in planktonic foraminiferal flux and assemblage composition in the Cariaco Basin, Venezuela. Journal of Foraminiferal Research 33 (3), 192-210.

Ternois, Y., Sicre, M.-A., Boireau, A., Beaufort, L., Miquel, J.-C., Jeandel, C., 1998. Hydrocarbons, sterols and alkenones in sinking particles in the Indian Ocean sector of the Southern Ocean. Organic Geochemistry 28, 489-501.

Ternois, Y., Kawamura, K., Ohkouchi, N., Keigwin, L., 2000. Alkenone sea surface temperature in the Okhotsk Sea for the last $15 \mathrm{kyr}$. Geochemical Journal 34, 283-293.

Thornalley, D.J.R., Elderfield, H., McCave, N., 2009. Holocene oscillations in temperature and salinity of the surface subpolar North Atlantic. Nature 457, 711-714.

Thunell, R.C., Curry, W.B., Honjo, S., 1983. Seasonal variation in the flux of planktonic foraminifera: time series sediment trap results from the Panama Basin. Earth and Planetary Science Letters 64 (1), 44-55.

Visser, K., Thunell, R., Stott, L., 2003. Magnitude and timing of temperature change in the Indo-Pacific warm pool during deglaciation. Nature 421, 152-155.

Waelbroeck, C., Frank, N., Jouzel, J., Parrenin, F., Masson-Delmotte, V., Genty, D. 2008. Transferring radiometric dating of the last interglacial sea level high stand to marine and ice core records. Earth and Planetary Science Letters 265, 183-194.

Weldeab, S., Schneider, R.R., Kölling, M., 2006. Deglacial sea surface temperature and salinity increase in the western tropical Atlantic in synchrony with high latitude climate instabilities. Earth and Planetary Science Letters 241, 699-706.

Weldeab, S., Lea, D.W., Schneider, R.R., Andersen, N., 2007a. 155,000 years of West African monsoon and ocean thermal evolution. Science 316 1303-1307.

Weldeab, S., Schneider, R.R., Müller, P., 2007b. Comparison of Mg/Ca- and alkenonebased sea surface temperature estimates in the fresh water-influenced Gulf of Guinea, eastern equatorial Atlantic. Geochemistry, Geophysics, Geosystems 8, Q05P22. doi:10.1029/2006GC001360.

Xu, J., Holbourn, A., Kuhnt, W., Jian, Z., Kawamura, H., 2008. Changes in the ther mocline structure of the Indonesian outflow during Terminations I and II. Earth and Planetary Science Letters 273, 152-162.

Zhao, M., Beveridge, N.A.S., Shackleton, N.J., Sarnthein, M., Eglinton, G., 1995 Molecular stratigraphy of cores off northwest Africa: sea surface temperature history over the last $80 \mathrm{ka}$. Paleoceanography 10, 661-675.

Zhao, M., Huang, C.-Y., Wang, C.-C., Wei, G., 2006. A millennial-scale Uk'37 sea surface temperature record from the South China Sea $\left(8^{\circ} \mathrm{N}\right)$ over the last 150 kyr: monsoon and sea level influence. Palaeogeography, Palaeoclimatology, Palaeoecology 36, 39-55 